\title{
Review \\ Exosomes in Parkinson: Revisiting Their Pathologic Role and Potential Applications
}

\author{
Yassamine Ouerdane ${ }^{1,+}{ }^{\dagger}$, Mohamed Y. Hassaballah ${ }^{2,+}{ }^{\circledR}$, Abdalrazeq Nagah ${ }^{2}$, Tarek M. Ibrahim ${ }^{3}(\mathbb{D}$, \\ Hosny A. H. Mohamed ${ }^{2}$, Areej El-Baz ${ }^{2}$ and Mohamed S. Attia ${ }^{3, * \mathbb{B}}$ \\ 1 Faculty of Medicine, Saad Dahlab University, Blida 09068, Algeria; ouerdaneyassamine@gmail.com \\ 2 Faculty of Pharmacy, Zagazig University, Zagazig 44519, Egypt; 14129@stemegypt.edu.eg (M.Y.H.); \\ Abdalrazeqnagah@gmail.com (A.N.); hosnyahmedhosny2020@gmail.com (H.A.H.M.); \\ a.elbaz21@pharmacy.zu.edu.eg (A.E.-B.) \\ 3 Department of Pharmaceutics, Faculty of Pharmacy, Zagazig University, Zagazig 44519, Egypt; \\ telmetwally@zu.edu.eg \\ * Correspondence: mosalahnabet@gmail.com or msalahatia@zu.edu.eg; Tel.: +20-01146696987; \\ Fax: +05-52303266 \\ + These authors have contributed equally to this work.
}

Citation: Ouerdane, Y.;

Hassaballah, M.Y.; Nagah, A.; Ibrahim, T.M.; Mohamed, H.A.H.; El-Baz, A.; Attia, M.S. Exosomes in Parkinson: Revisiting Their Pathologic Role and Potential Applications. Pharmaceuticals 2022, 15, 76. https://doi.org/10.3390/ ph15010076

Academic Editor: Ramya

Lakshmi Rajendran

Received: 26 November 2021

Accepted: 3 January 2022

Published: 7 January 2022

Publisher's Note: MDPI stays neutral with regard to jurisdictional claims in published maps and institutional affiliations.

Copyright: (c) 2022 by the authors. Licensee MDPI, Basel, Switzerland. This article is an open access article distributed under the terms and conditions of the Creative Commons Attribution (CC BY) license (https:/ / creativecommons.org/licenses/by/ $4.0 /)$.

\begin{abstract}
Parkinson's disease (PD) is a progressive neurodegenerative disorder characterized by bradykinesia, rigidity, and tremor. Considerable progress has been made to understand the exact mechanism leading to this disease. Most of what is known comes from the evidence of PD brains' autopsies showing a deposition of Lewy bodies—containing a protein called $\alpha$-synuclein $(\alpha$-syn) —as the pathological determinant of PD. $\alpha$-syn predisposes neurons to neurotoxicity and cell death, while the other associated mechanisms are mitochondrial dysfunction and oxidative stress, which are underlying precursors to the death of dopaminergic neurons at the substantia nigra pars compacta leading to disease progression. Several mechanisms have been proposed to unravel the pathological cascade of these diseases; most of them share a particular similarity: cell-to-cell communication through exosomes (EXOs). EXOs are intracellular membrane-based vesicles with diverse compositions involved in biological and pathological processes, which their secretion is driven by the NLR family pyrin domain-containing three proteins (NLRP3) inflammasome. Toxic biological fibrils are transferred to recipient cells, and the disposal of damaged organelles through generating mitochondrial-derived vesicles are suggested mechanisms for developing PD. EXOs carry various biomarkers; thus, they are promising to diagnose different neurological disorders, including neurodegenerative diseases (NDDs). As nanovesicles, the applications of EXOs are not only restricted as diagnostics but also expanded to treat NDDs as therapeutic carriers and nano-scavengers. Herein, the aim is to highlight the potential incrimination of EXOs in the pathological cascade and progression of PD and their role as biomarkers and therapeutic carriers for diagnosing and treating this neuro-debilitating disorder.
\end{abstract}

Keywords: exosomes; neurodegenerative diseases; $\alpha$-synuclein; Parkinson's disease; therapeutic; biomarker; lewy bodies

\section{Introduction}

Neurodegenerative diseases (NDDs) are considered irreversible deterioration and loss of neurons in different areas of the central nervous system (CNS). Therefore, neuronal damage occurring in the intellectual or cognitive locus can cause significant worsening in the patient's clinical condition and lifestyle. Recently, it has been acknowledged that genetic and environmental factors can invoke certain types of NDDs [1].

Over the past years, NDDs prognosis was problematic because of poor drug access to the brain. Thus, the systemic delivery of drugs to the CNS is still challenging. Various factors may impede the drug uptake, such as extensive first-pass metabolism, reduced elimination half-life $\left(t_{\frac{t}{2}}\right)$, and the possible side effects that may occur when reaching the 
non-target peripheral tissues [2]. The treatment approach for Parkinson's disease (PD) is to compensate for the dopamine (DA) depletion in the brain and improve the motor symptoms. The first DA analog is levodopa (L-Dopa). Patients treated with this agent have experienced a functional benefit of decreased motor and non-motor symptoms [3].

PD is one of the most common NDDs, and its incidence is proportional to age. It emerged as an age-related disease since it exhibits a high prevalence of 0.41 per 100,000 in individuals over 40 years and 1900 per 100,000 in individuals over 80 years [4]. In addition, the disease's pathogenicity is due to the degeneration of dopaminergic neurons at the substantia nigra pars compacta, also named as the dark substance, which is the DAproducing region. This region can control body movement, cognitive functions, and emotional activities.

Hence, most signs of PD are related to motor disability, such as bradykinesia, tremors, and rigidity $[4,5]$. These signs appear at one side of the body, worsen, and affect the other side. Some cognitive disorders such as dementia, sleep disturbance, anxiety, depression, psychosis, and speech disorders may appear [6]. Furthermore, Lewy bodies accumulation is the pathological determinant of PD. They are spherical and contain a protein called $\alpha$-synuclein ( $\alpha$-syn). These bodies appear after the depletion of dopaminergic neurons at the substantia nigra pars compacta $[7,8]$, explaining why $\alpha$-syn gene overexpression or mutation is strongly associated with PD and dementia with Lewy bodies accumulation $[9,10]$.

Furthermore, genes have a vital role in the progression of PD; for example, a mutation in the leucine-rich repeat kinase 2 (LRRK-2) gene can lead to familial or classical PD as it contributes to Lewy bodies aggregation [11,12].

Exosomes (EXOs) are intracellular membrane-based vesicles with diverse compositions involved in biological and pathological processes [13]. Until now, EXOs' function in the brain is not fully understood. Still, it is found that these vesicles can regulate cellular communication within the CNS and perform an essential role in keeping the brain's physiology. EXOs can mediate the myelination and axons survival by controlling the neuron-oligodendrocytes communication, as EXOs release is stimulated by glutamate secretion and then uptaken by neurons through endocytosis [14-16]. Moreover, EXOs have a neuroprotective role, which is observed upon the addition of EXOs derived from oligodendrocytes to cultured neurons leading to an increment in cell viability even under stress conditions [14,15]. It was reported that EXOs had a synaptic plasticity role as the microtubule-associated protein $1 \mathrm{~b}(\mathrm{MAP} 1 \mathrm{~b})$, a synaptic plasticity-associated protein, is released from EXOs during neurons depolarization [14].

EXOs are considered ideal non- or less invasive biomarkers for diagnosing various diseases, such as PD, as they can be detected in different body fluids and tissues [17]. Furthermore, different proteins from host cells enriched in EXOs can be used as biomarkers themselves [18]. The potentiality of PD diagnosis using EXOs arises from the accumulation of $\alpha$-syn, a pivotal PD manifestation transmitted among neurons through EXOs. EXOs release is stimulated by NLR family pyrin domain-containing three protein (NLRP3) inflammasome activation in microglia and subsequent release of pro-inflammatory cytokines, which are significant events related to PD progression [19].

The potential of EXOs for drug delivery is based on their size and competence to transfer biological materials to recipient cells [20]. Naturally produced EXOs have evolved to surpass the challenges for other drug delivery systems, including liposomes and polymeric nanoparticles [21,22]. However, the high stability and circulation capability of liposomal systems are limited by the increased toxicity and immunogenicity [23]. Though polymeric nanoparticles can solve the stability issue, their toxicity and biocompatibility remain a major concern, especially when using non-biodegradable polymers [24]. Owing to their natural origin, EXOs can exhibit a limited long-term accumulation in most organs, leading to almost no systemic toxicity [25]. EXOs are highly biocompatible with various biological systems; thus, they are selected as natural drug delivery vehicles for various therapeutic cargo [26]. Therefore, an exosomal drug delivery system with minimal toxicity, high bio- 
compatibility, tissue and tumor targeting, and long-circulating $t_{\frac{t}{2}}$ becomes a more practical choice, conquering the drawbacks of liposomes or polymeric nanoparticles [21].

\section{Overview of Extracellular Vesicles}

Over the past decade, the small endosomal derived membrane microvesicles, EXOs, have gained more attention and interest. In addition to their presence in the extracellular space, they are secreted from cells as a cellular waste of cell damage or by-products of cell homeostasis without remarkable effect on neighboring cells [27]. Those functional extracellular vesicles can carry a complex cargo of proteins, lipids, and nucleic acids and deliver these cargoes to the target cells [28]. Since EXOs can be released by all eukaryotic cells, their cargos are considerably different, corresponding to the function of originated cells and their current state. Therefore, EXOs and their cargoes can indicate various diseases such as neurodegenerative, cardiovascular, renal, and metabolic diseases [29].

\subsection{EXOs Biogenesis}

EXOs are generated from late endosomes by inward budding of the limited multivesicular body (MVB) membrane and is followed by the invagination of late endosomal membranes and the formation of intraluminal vesicles (ILVs) within large MVBs. During this process, specific proteins are incorporated into the invaginating membrane while the cytosolic components are engulfed within the ILVs. Most ILVs, referred to as "EXOs", are released into the extracellular space upon fusion with the plasma membrane [30].

\subsection{EXOs Structure}

Various elements have been identified in EXOs in terms of specially sorted proteins, lipids, nucleic acids representing the structure complexity and potential functional diversity of EXOs [31]. EXOs are highly enriched in multifunctional proteins, for example, tetraspanins, heat shock proteins, and MVB formation proteins. These proteins participate in cell penetration, antigen binding, and release of EXOs, respectively [32].

Furthermore, the lipid architecture displays the EXOs bioactivity, as shown in Figure 1. EXOs are enriched in cholesterol, phosphatidylserine, sphingomyelin, phosphatidic acid, prostaglandins, and leukotrienes. These lipid components support the structural rigidity and stability of EXOs [33]. In addition, EXOs possess some lipolytic enzymes capable of producing various bioactive lipids to be internalized into target cells with a concentration of lipid mediators within the endosomes. Therefore, EXOs can offer diagnostic and prognostic information about various lipid-related diseases [27].

EXOs also contain various RNAs that can be incorporated into recipient cells. MicroRNAs (miRNAs) are abundant in human plasma-derived exosomal RNA species [34]. When miRNAs are packed into EXOs, they show unidirectional transfer between cells with the formation of an intercellular trafficking network that can produce phenotypic changes in recipient cells [35]. Besides miRNAs, long non-coding RNAs (lncRNAs) and circular RNAs (circRNAs) are present in EXOs influencing several biological processes such as the development of tumor and regulation of tumor microenvironment [36]. In addition, CircRNAs are proposed as a possible tumor diagnostic marker owing to their high stability and non-susceptibility to exonuclease cleavage [37]. 


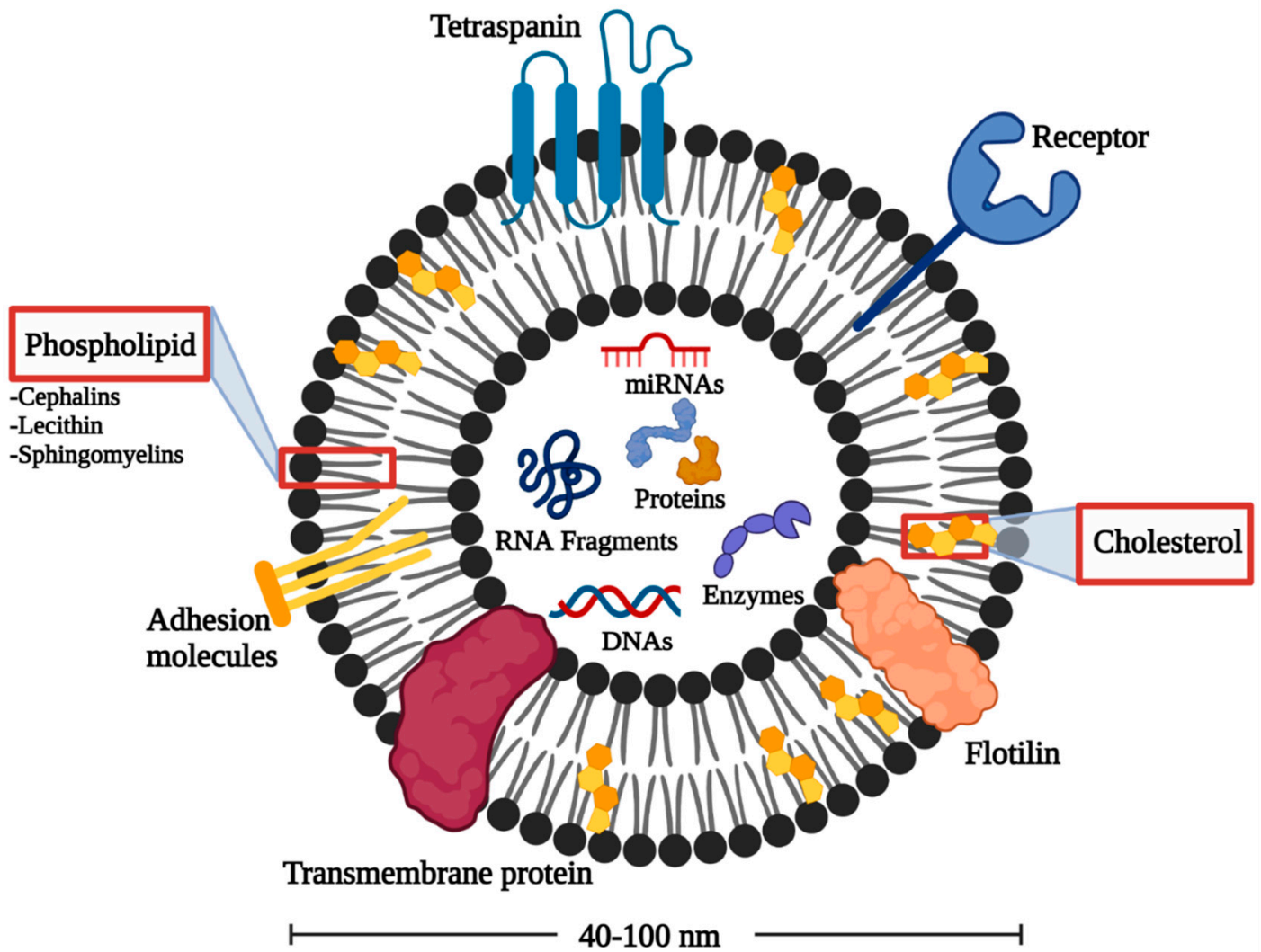

Figure 1. Architecture of EXOs.

\subsection{Isolation of EXOs}

Several methods have been used for EXOs isolation from the natural biofluids such as blood, urine, and cerebrospinal fluid (CSF). The most used technique is differential ultracentrifugation, which separates the needed particles according to their size and density; this technique is considered the gold standard for exosomal isolation [38]. Lately, classical techniques have waned due to modern technological advancement; thus, other methods have emerged; the disadvantage that made researchers revert to the differential ultracentrifugation technique is the possible contamination of the final product with samesized particles creating exosomal aggregates [39]. Precipitating agents such as polyethylene glycol-based precipitation, immunoaffinity capture, microfluidics, and size-exclusion chromatography have emerged as alternatives, and each technique has specific criteria and strength points [40]. It is believed that using cost-effective approaches that are readily available will make EXOs applicable in treating NDDs in the foreseeable future.

\section{Pathogenesis of PD}

\subsection{The $\alpha$-Syn Role}

Misfolding and aggregation of $\alpha$-syn and its deposition in Lewy bodies result in autonomous-mediated neurotoxicity linked to PD. The pathogenesis of PD is mainly via the non-cell autonomous-mediated neurotoxicity and cell-to-cell transmission of $\alpha$-syn [41,42].

$\alpha$-syn monomers are amino-terminally acylated and thereby adopt a compact conformation. They can assemble into oligomers, and the latter continue to aggregate, forming soluble protofibrils or filaments; if a change in structure occurs, these filaments become insoluble fibrils $[43,44]$. Noting that the prefibrillar oligomers are more toxic than mature aggregated fibrils due to their ability to seed and accelerate the aggregation of $\alpha$-syn monomers (Figure 2). Several reasons made it essential to focus on the widespread of these aggregates in PD. First, the larger oligomers or protofibrils have been shown to impair the function of several cytosolic organelles such as the mitochondria and endoplasmic 
reticulum, thereby disrupting the electrophysiological function of the synapse. Second, consider the potential spreading of $\alpha$-syn aggregates between interconnected brain regions acting as seeds to propagate disease.

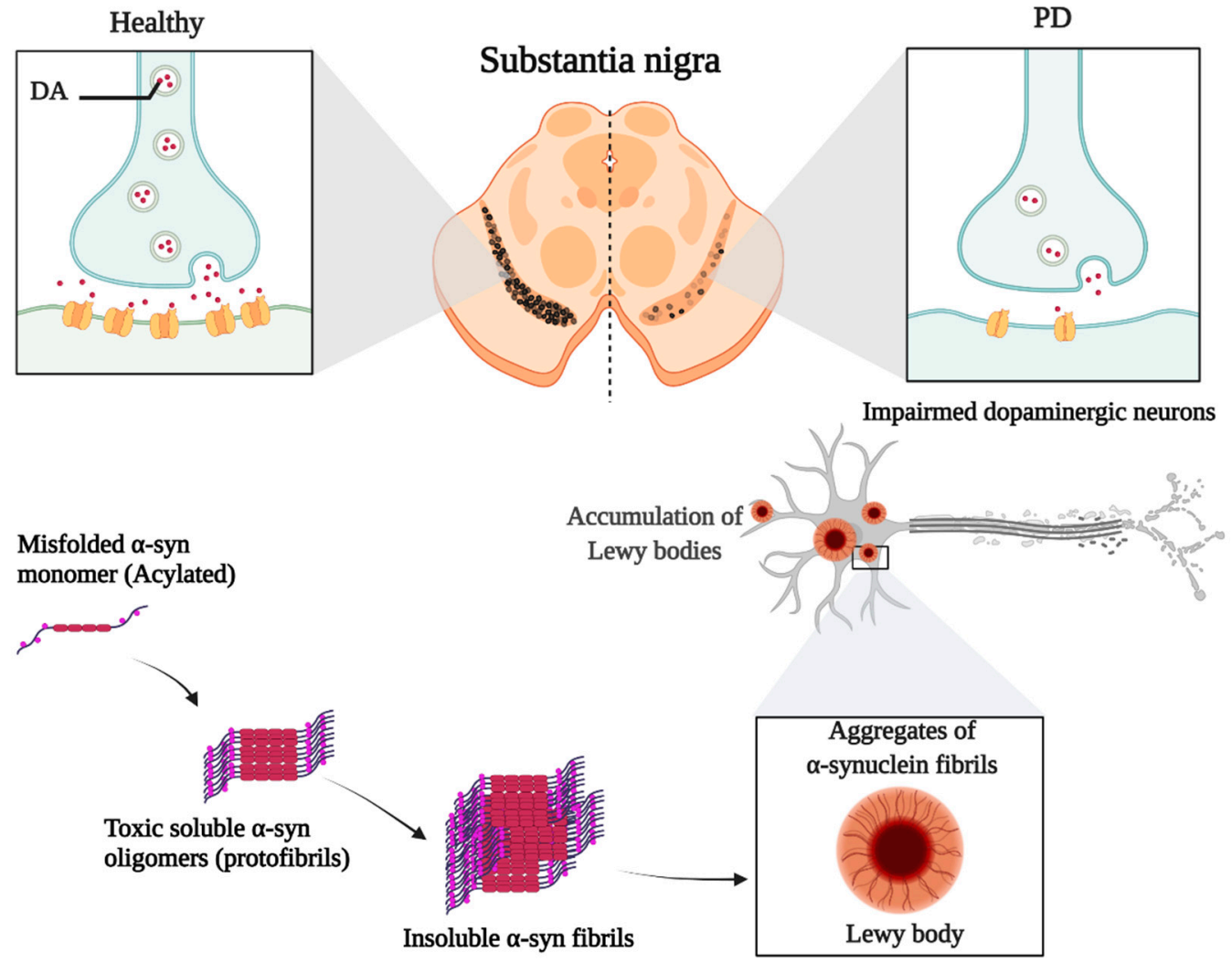

Figure 2. The role of $\alpha$-syn in the development of PD.

\subsection{The Role of EXOs in Spreading $\alpha$-Syn}

EXOs are molecular-carrying vesicles that have an essential role in transferring molecules, including microRNAs (miRNAs) and proteins, between neighboring cells as a part of cell-to-cell communication $[19,45]$. Thus, EXOs are essential components in different disease pathogenic mechanisms via cell-to-cell communication, which is the basis of their role in PD pathogenesis and progression. They may promote the PD progression by regulation, uptake, and transfer of aberrant $\alpha$-syn and inflammatory mediators, transferring them to neighboring cells $[19,41,45]$. It has been reported that EXOs can shuttle $\alpha$-syn oligomers from damaged neurons to normal neurons (Figure 3), leading to induction of aggregates formation and cell death [46]. In addition, EXOs can increase the likelihood of neurotoxicity mediated by $\alpha$-syn since these oligomers associated with EXOs possess higher cellular uptake and neurotoxicity than non-extracellular vesicles (EVs) oligomers [41,46-48].

The $\alpha$-syn-associated EXOs can be released through the intracellular vesicle trafficking process (Figure 3). When the early endosome process takes place, $\alpha$-syn is internalized into ILVs and accumulates inside the MVB. Afterward, MVB containing ILVs undergoes fusion with the plasma membrane and releases ILVs as EXOs $[41,49,50]$. MVBs can also fuse with autophagosomes forming amphisomes and autophagic intermediates that can fuse with the plasma membrane to release EXOs containing $\alpha$-syn $[41,42]$.

Several in vitro studies demonstrated that EXOs could accelerate the aggregation of $\alpha$-syn when EXOs were isolated from CSF of PD patients [41,46]. In contrast, EXOs isolated from the CSF of control patients did not influence the $\alpha$-syn aggregation in any manner $[1,3]$. In addition, it was also found that EXOs of PD patients could induce dopaminergic neurons degeneration and motor deficits when injected into the striatum of mice [46,51-53]. 


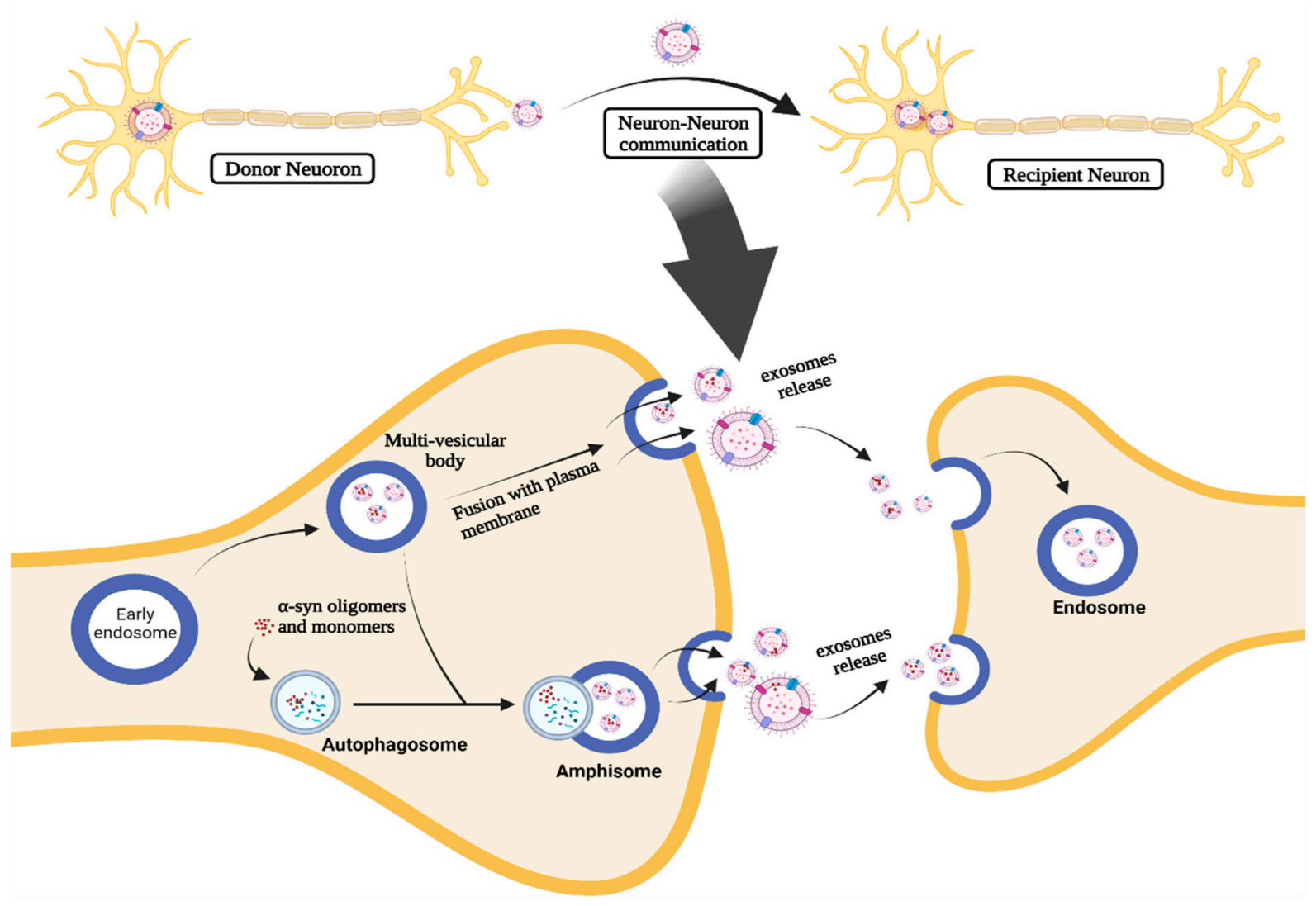

Figure 3. The role of EXOs in cell-to-cell communication in PD.

Both in vitro and in vivo testing had demonstrated that microglia could internalize the $\alpha$-syn-containing EXOs, inducing microglia activation and $\alpha$-syn aggregation [51]. The stimulation of BV-2 microglia via $\alpha$-syn could lead to the release of EXOs, which could induce apoptosis of recipient neurons. In addition, the accumulation of $\alpha$-syn after microglial activation could lead to motor deficits resulting from losing dopaminergic neurons [45,51,52].

It was indicated that both small and large structures of $\alpha$-syn could travel within EXOs among neurons, which resulted in neurotoxicity. This was proved by the over-expression of $\alpha$-syn in SH-SY5Y neuroblastoma cells that led to its exosomal release [41]. In addition, both monomeric and oligomeric $\alpha$-syn were detected inside the EXOs $[41,46,47,54]$.

It was proven that the autophagy-lysosomal pathway was also involved in $\alpha$-syn transmission through EXOs. This could be observed in cases of lysosomal inhibition in donor cells as it was found to increase exosomal release and transmission of $\alpha$-syn [41,42]. The MVB and amphisomes effects are promoted as a compensatory mechanism to prevent excessive aggregation of intracellular $\alpha$-syn. Although this mechanism initially decreases the intracellular $\alpha$-syn levels, which seems a protective measure, it leads to the enhanced transmission of $\alpha$-syn through exosomal release, resulting in PD progression and an overloaded extracellular space with neurotoxic $\alpha$-syn $[41,55,56]$.

Microglia's principal function is to degrade extracellular $\alpha$-syn and remove aggregated proteins in different brain areas through phagocytosis. The microglia-mediated neuroinflammation was provoked by $\alpha$-syn inducing the release of pro-inflammatory cytokines, which were proved to be involved in PD progression and pathogenesis $[57,58]$. The exact mechanism was illustrated that $\alpha$-syn stimulates microglia via the Kv1.3 voltage-gated potassium channel, leading to a significant increase in neuroinflammation and neurodegeneration [59]. Furthermore, activated microglia-releasing EXOs are responsible for transmitting inflammatory mediators, such as IL- $1 \beta$, IL-18, and TNF- $\alpha$, from glia-to-glia or glia-to-neuron, which are the most common vital reasons for induction of dopaminergic 
neuron degeneration in PD patients $[57,58]$. Then, this vicious cycle continues as those neurons release $\alpha$-syn-containing EXOs that activate microglia, repeating the whole process.

\section{EXOs as a Future Approach for PD Diagnosis}

The current approach for PD diagnosis is based on neurological symptoms and imaging techniques for the brain. Those methods are usually imprecise and time consuming, requiring the physician to monitor the patient for some time before confirming the diagnosis [60-62]. Biomarkers with a high level of reliability are necessary for the future of PD diagnosis, disease progression monitoring, and treatment response assessment $[61,63]$. The most challenging obstacle in identifying reliable biomarkers is that PD is restricted in a certain subset of neurons in a specific location of the CNS. Based on this view, EVs released from those specific neural cells circulate in CSF, and blood can be PD biomarkers as indicated in Table 1 [64].

Various cells in the CNS, such as microglia and astrocytes, can release EXOs, which are initially thought to be a mechanism by which the cell eliminates unnecessary proteins. However, recent work suggested a pivotal role for these organelles as mediators for cell-to-cell communication. As discussed before in previous sections, EXOs are the potential culprit in the PD progression $[54,65]$. One reason that makes it crucial to study the involvement of EXOs as diagnostic biomarkers in PD is its consistent relationship with various pathological mechanisms in PD. EXOs can help dispose of damaged organelles by generating mitochondrial-derived vesicles and thus participate in mitochondrial quality control (MQC). Abnormal EXOs secretion and MQC breakdown are both alleged in the pathogenesis of PD by triggering the disposition of $\alpha$-syn and consequently leading to dopaminergic neurotoxicity [66]. Another mechanism is crucially linked to the impaired EXOs release in sporadic and hereditary PD patients [67]. The autophagy-lysosome pathway (ALP) regulates EXOs production and release by autophagy induction which promotes EXOs release, and autophagy stimulation which inhibits EXOs release [68,69]. This impairment indicates that EXOs release may increase PD [67]. Indeed, ALP modulators as bafilomycin can prevent autophagosome-lysosome fusion, increasing $\alpha$-syn release from EXOs [42,55]. Smaller oligomers were released via EXOs and RAB11A-associated pathways, while high-aggregated gamma-syn was secreted by membrane shedding [55].

The environmental contaminant rotenone (RTN) inhibits mitochondrial complex I, causing PD [70]. RTN inhibits mitochondrial, autophagic, and lysosomal processes [71]. Enteric neurons treated with RTN produce more EXOs-containing $\alpha$-syn [72]. On the other hand, rapamycin, an autophagy enhancer, unlike the RTN, reduced the $\alpha$-syn oligomer released from EXOs. Collectively, it can be assumed that increasing autophagic activity reduces EXOs release, thus protecting neurons from neurological damages [73].

Moreover, EXOs contain different proteins and miRNAs that play critical roles in the occurrence of PD. For example, after analyzing the genomic sequences of miRNA133 obtained from PD patients' blood samples shows an increase in the frequency of miR-133b variant (90 del A) in PD patients. The latter is involved in dopamine neuron survival in mice $[74,75]$. In the upcoming sections, we have analyzed the results obtained from different delivery methods for miRNA-based therapy using exosomes as a core-shell to potentiate neuronal survival and differentiation. Thus, EXOs are considered a unique class of PD biomarkers, with less or no invasion [61,65,76,77]. Collectively, the previous data implies that the study of substances packaged in body fluids and released by EVs may help us comprehend the connection between systemic PD inflammation and its potential incrimination as a biomarker for PD.

Jiang et al. studied protein changes in serum EXOs derived from severe or moderate PD patients, and 14 proteins were significantly changed [78]. PD patients showed high expression of seven proteins, including pigmented factor produced from epithelium, afamin, and apolipoprotein D and J. Seven proteins had decreased expression in PD patients, including C1q supplements IGLV1-33 clusters. 
miRNAs are enriched in EXO-like vesicles secreted from different types of cells, including neural cells involved in the progression of PD [61]. Those vesicles were found in different sizes ranging from $40-100 \mathrm{~nm}$, assessed in CSF, blood, saliva, urine, and tears. miRNAs have shown their potential in the prognosis and determination of staging and development of PD [61,79]. As prognostic biomarkers, they can distinguish between different stages of the disease, which is ultimately crucial in the treatment and diagnosis of PD patients. Gui et al. studied reliable biomarkers, using a list of 24 miRNAs showing significant differences between patients with PD. Healthy controls showed specific results indicating that miR-1, miR-19b-3p, miR-153, miR-409-3p, miR10a-5p, and let-7g-3p are reliable biomarkers of PD. Those miRNAs in CSF demonstrated sufficient specificity and sensitivity to discriminate between PD and Alzheimer's disease (AD) patients [61,80-86].

The stability of EXOs containing miRNA had been studied and assured for being utilized as biomarkers for PD. Compared with control groups, using RT-qPCR analysis, it was found that miR-24 and miR19b were significantly downregulated in patients with PD, whereas miR-195 was upregulated, representing high reliability and reproducibility as biomarkers $[61,87]$. Therefore, the level of miRNAs such as miR-195, miR-19b, and miR-24 can be correlated with PD progression. Other types of miRNA have the potentiality to be used as effective and dependable biomarkers, but some related information cannot be demonstrated due to different limitations toward sample size and test reproducibility [61].

Recent studies found that EXOs secretion was remarkably higher in PD patients than in healthy controls attributed to the primary role EXOs in transferring $\alpha$-syn, which promotes their production to transfer the aggregated $\alpha$-syn $[52,65,88]$. From in vivo experiments, pathological $\alpha$-syn containing EXOs could be taken up by healthy neurons and induce a similar cascade of pathological events as seen in the PD brain. Thus, an efficient experiment that illustrated the importance of EXOs as a diagnostic biomarker could be efficiently designed and performed on this basis $[65,86]$. Microglial $\alpha$-syn-containing EXOs were inoculated, leading to the induction of $\alpha$-syn aggregation, causing the development in PD in mice. In addition, these EXOs have triggered the loss of dopaminergic neurons leading to PD-like motor deficits with time $[65,86]$. Another protein associated with an increased risk of PD is LRRK-2, a kinase enzyme encoded by the LRRK2 gene in humans, which is a member of the leucine-rich repeat kinase family. Mutations in LRRK-2 can enhance the auto-phosphorylated LRRK-2 protein levels, and they are the most commonly known cause of inherited PD. The LRRK-2 protein includes two enzymatic domains proven to have guanosine triphosphatase (GTPase) and protein kinase activity. One of the most abundant autophosphorylation sites is in the Serine- 1292 residue near the GTPase domain. This autophosphorylation at Serine-1292 $\left(\mathrm{pS}_{1292}\right)$ leads to neurotoxicity since these proteins can be packaged into EXOs. Thereby, measuring the EXOs-harbored LRRK-2 may be of particular importance as a biomarker in PD diagnosis. Fraser et al. found elevated $\mathrm{pS}_{1292-}$ LRRK-2 levels in urinary EXOs from mutation carriers versus controls [89].

Moreover, a discrete difference between PD patients' saliva components and those obtained from healthy controls was observed. The proteomic study by Figura et al. showed that the saliva from 39 PD patients had lower concentrations of S100-A16, ARP2/3, and VPS4B than the control group [90]. These proteins are involved in various metabolic and inflammatory pathways. The S100A 16 is a protein that potentially participates in calciumbinding and adipose tissue formation [91]. Several studies confirmed the association of the S100 protein family with PD [92] and other neurological diseases such as AD and neuronal injury [93-95]. The actin-related protein $2 / 3$ complex (ARP2/3) protein is involved in forming the actin network in the cytosol, thus participating in cell motility [96]. As for the VPS4B, it was observed to decrease in PD patients' saliva. VPS4B is involved in the endosomal vesicular release of a subset of proteins and the EXOs secretion pathway [97]. The authors suggested that the observed decrease in VPS4B might be due to its increased uptake by EXOs [90].

Furthermore, Galindez et al. [98] revealed elevated heme oxygenase-1 (HO-1) concentrations in the PD group compared to controls. Heme oxygenase (HMOX) is an enzyme 
that degrades heme into biliverdin, ferrous iron, and carbon monoxide [99]. In response to oxidative stress, the isoform (HO-1) becomes a culprit contributing to a more permeable BBB and the marked increase in iron deposition in the PD brain [100]. Of note, the HO-1 protein in human biofluids, including saliva, is localized mainly in EV compartments such as EXOs [101]; thus, future studies could focus on evaluating the level of EXO content of $\mathrm{HO}-1$ protein in PD patients.

Table 1. Exosomal biomarkers isolated in cohort studies for PD diagnosis.

\begin{tabular}{|c|c|c|c|c|c|}
\hline Source & Potential Biomarkers & Findings & $p$-Value & Patient N & Ref \\
\hline \multirow{3}{*}{ Plasma } & CNS-derived EXOs $\alpha$-syn & $\uparrow$ & $p=0.004$ & 267 PD, 215 controls & {$[88]$} \\
\hline & miR-331-5p & $\uparrow$ & \multirow{2}{*}{$p<0.05$} & \multirow{2}{*}{$52 \mathrm{PD}, 48$ controls } & \multirow{2}{*}{ [102] } \\
\hline & miR-505 & $\downarrow$ & & & \\
\hline \multirow{4}{*}{ Serum } & $\begin{array}{l}\text { Pigmented epithelium-derived factor, } \\
\text { Afamin, apolipoprotein D, and J }\end{array}$ & $\uparrow$ & \multirow{2}{*}{$p<0.05$} & \multirow{2}{*}{$20 \mathrm{PD}, 10$ controls } & \multirow{2}{*}[78]{} \\
\hline & Complement C1q & $\downarrow$ & & & \\
\hline & miR-19b & $\downarrow$ & \multirow{2}{*}{$p<0.05$} & \multirow{2}{*}{109 PD, 40 controls } & \multirow{2}{*}[61]{} \\
\hline & miR-24, miR-195 & $\uparrow$ & & & \\
\hline \multirow{3}{*}{ CSF } & $\alpha$-syn & $\downarrow$ & $p<0.05$ & $76 \mathrm{PD}, 58$ controls & [103] \\
\hline & miR-1 and miR-19b-3p & $\downarrow$ & \multirow[b]{2}{*}{$p<0.05$} & \multirow[b]{2}{*}{$47 \mathrm{PD}, 27$ controls } & \multirow[b]{2}{*}{ [86] } \\
\hline & $\begin{array}{l}\text { miR-153, miR-409-3p, miR-10a-5p, } \\
\text { and let-7g-3p }\end{array}$ & $\uparrow$ & & & \\
\hline Urine & SerP-1292 LRRK2/total LRRK2 ratio & $\uparrow$ & $p=0.0014$ & 79 PD, 79 controls & [89] \\
\hline Saliva & S100-A16, ARP2/3, and VPS4B & $\downarrow$ & $p<0.05$ & $24 \mathrm{PD}, 15$ controls & [89] \\
\hline
\end{tabular}

\section{Treatment of PD}

Treatment with L-Dopa represents a key pillar for relieving PD symptoms [104], and it is associated with significant improvement in motor functions assessed by the Unified Parkinson's Disease Rating Scale (UPDRS), compared to other drugs [105-108]. In addition, the available drugs to treat PD suffer from pharmaceutical limitations, including low bioavailability, extensive metabolism, short $t_{\frac{t}{2}}$, and peripheral side effects. Treatment options for PD along with their challenging pharmacokinetic and peripheral side effects are discussed in Table 2.

Table 2. The challenging pharmacokinetic and peripheral side effects of PD treatment options.

\begin{tabular}{|c|c|c|c|c|}
\hline Name/Chemical Structure & Class & $\begin{array}{l}\text { Pharmacokinetic } \\
\text { Features }\end{array}$ & Peripheral Side Effects & Ref \\
\hline L-Dopa & $\begin{array}{l}\text { Dopamine } \\
\text { Precursor }\end{array}$ & $\begin{array}{l}\text { - } \quad \text { Oral Fa }(\%)= \\
31 \text { to } 33 \% \text { for } \\
1 \mathrm{~g} / \text { oral dose } \\
\text { - } \quad \text { Short } t_{\frac{t}{2}} \approx 30 \text { to } \\
60 \text { min for oral } \\
\text { LDopa }\end{array}$ & $\begin{array}{ll}\text { - } & \text { Upset GIT } \\
\text { - } & \text { Cardiac arrhythmia } \\
\text { - } & \text { Hypertension } \\
\text { - } & \text { "on/off" phenomena. } \\
\text { - } & \text { Dyskinesia on } \\
& \text { long-term } \\
\text { - } & \text { Postmerapy }(75 \%) \\
\text { bleeding }\end{array}$ & [109-115] \\
\hline
\end{tabular}


Table 2. Cont.

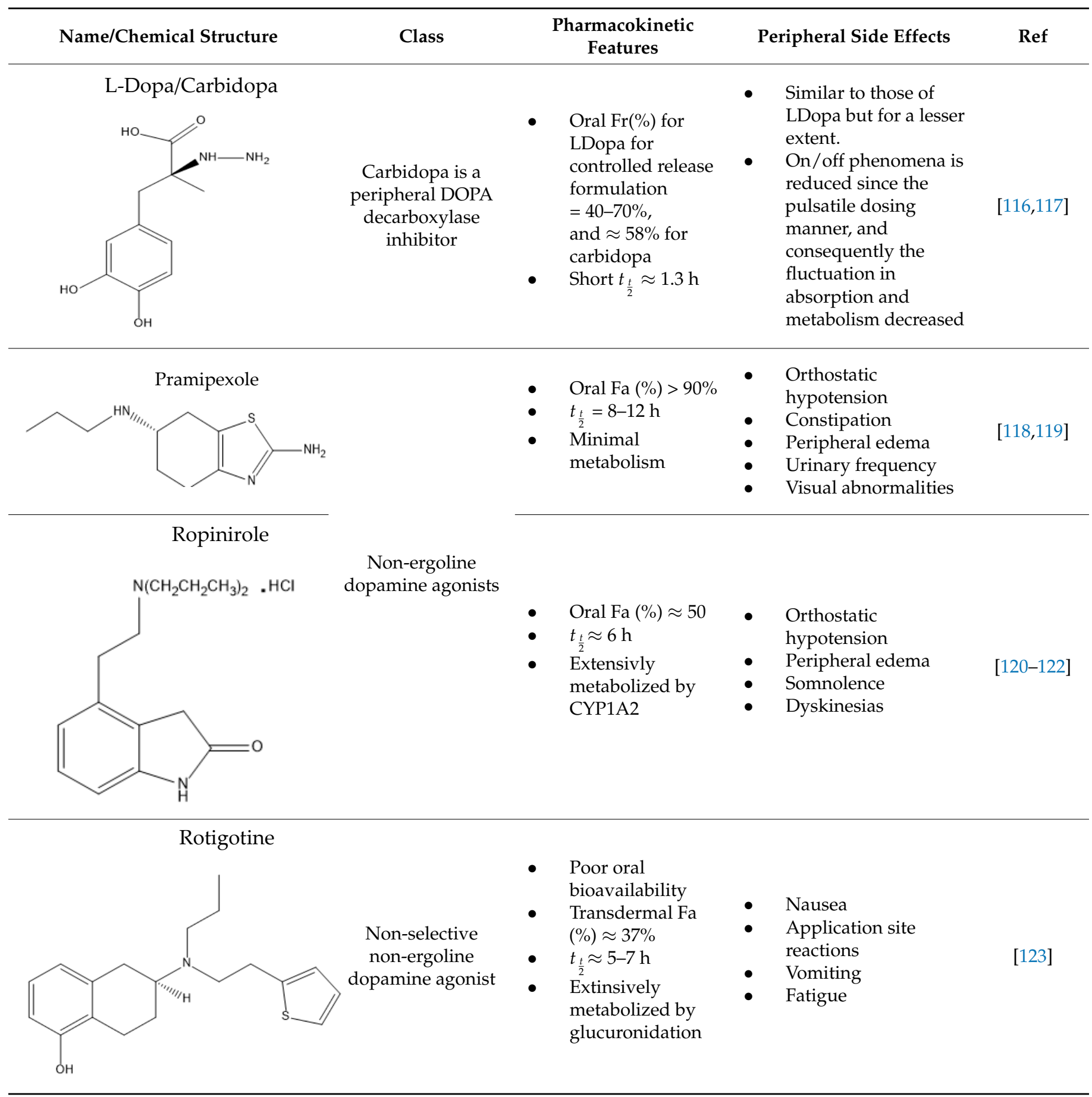


Table 2. Cont.
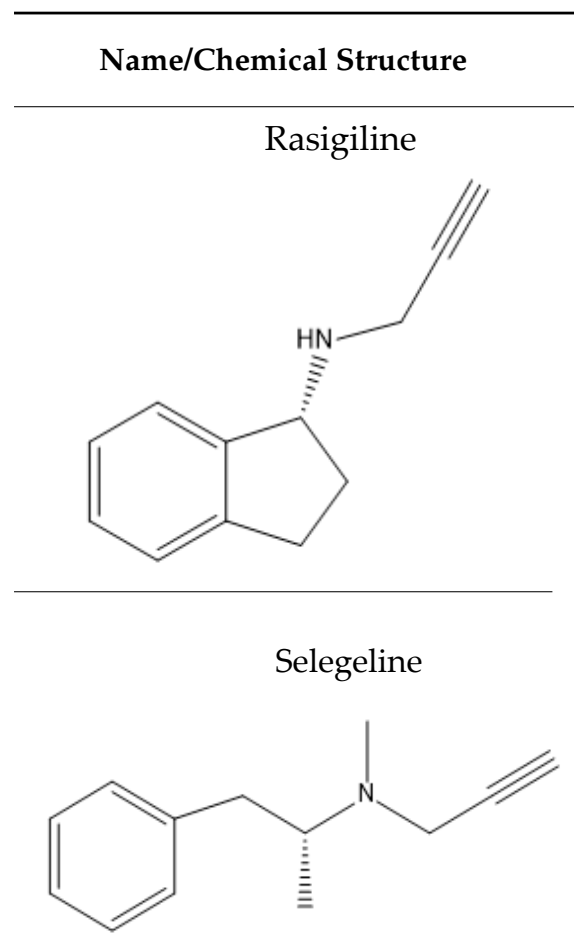

MAO B inhibitors

Safinamide

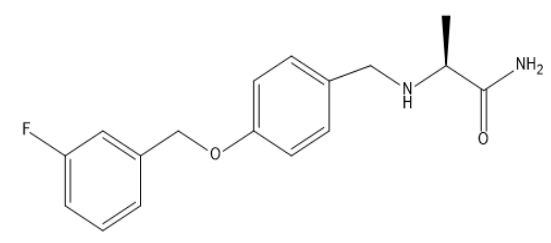

- $\quad$ Oral $\mathrm{Fa}(\%) \approx 95 \%$
- $\quad$

- $\quad$ Oral Fa $(\%) \approx 36$

- Short $t_{\frac{t}{2}} \approx 1.34 \%$

- $\quad$ Anorexia and weight loss

- Orthostatic hypotension
- $\quad$ Oral Fa $(\%) \approx 4.4 \%$

- Transdermal Fa $(\%) \approx 73 \%$

- $\quad t_{t}$ ranged from 15-25 after IV and transdermal delivery and 9-15 for oral dosing
- Constipation

- Insomnia

- Application-site reactions for

[126,127] transdermal delivery

- $\quad$ Peak dose dyskinesia
- Dyskinesia

- Retinopathy

- Backache

- Constipation

\section{Entacapone}<smiles>CCN(CC)C(=O)/C(C#N)=C/c1cc(O)c(O)c([N+](=O)[O-])c1</smiles>

- $\quad$ Oral Fa (\%) $\approx 25-35 \%$

- Extensivly metabolised

- $t_{\frac{t}{2}}=2.40 \pm 1.70 \mathrm{~h}$<smiles>Cc1ccc(C(=O)c2cc(O)c(O)c([N+](=O)[O-])c2)cc1</smiles>

- $\quad$ Oral Fa $(\%) \approx 65 \%$

- Short $t_{\frac{t}{2}}=2-3 \mathrm{~h}$

- Extensively metabolized by COMT
- Urine discoloration

- Diarrhea

- Peak dose dyskinesia

- Gastrointestinal effects
- Abdominal pain, diarrhea

- Dyskinesia

- Increase liver enzyme (fulminant hepatitis) 
Table 2. Cont.

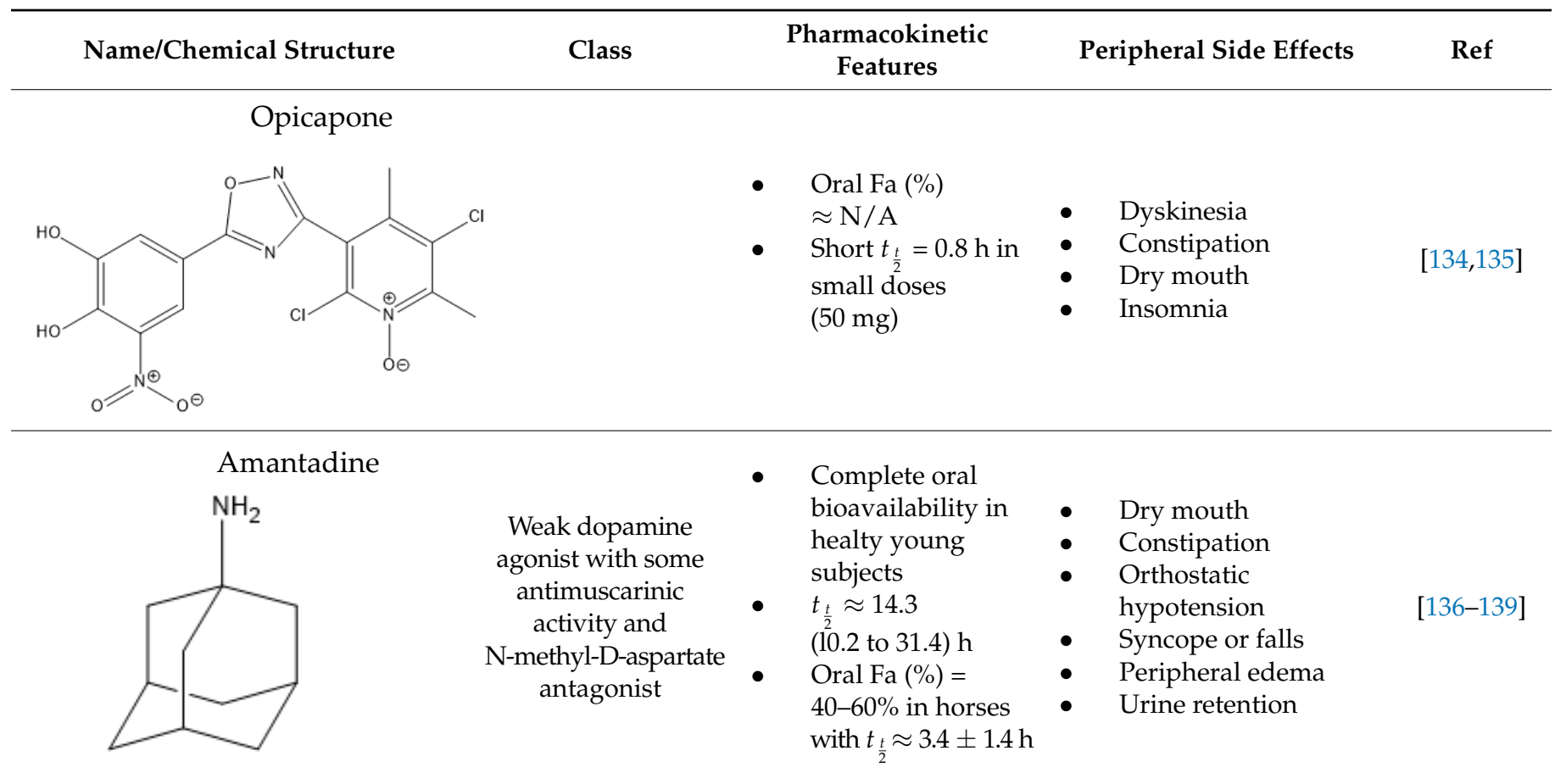

Apomorphine<smiles>CN1CCc2cccc3c2[C@H]1Cc1ccc(O)c(O)c1-3</smiles>

non-ergoline dopamine D1 and D2 agonist
- $\quad$ Sublingual Fr (\%) $=17-18 \%$ relative to SC

- $\quad$ Short $t_{\frac{t}{2}} \approx 45 \mathrm{~min}$

- About $60 \%$ of the sublingual dose is eliminated as a sulfate conjugate
- Constipation

- Sweating, Salivation

- Orthostatic
Procyclidine<smiles>OC(CC[NH+]1CCCC1)(c1ccccc1)C1CCCCC1</smiles>

Trihexyphenidyl

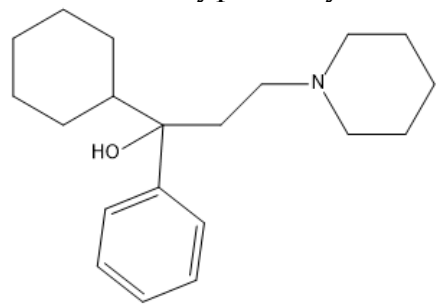

- $\quad$ Oral Fa $(\%) \approx 75 \%$

- $t_{\frac{t}{2}}$ is up to $12 \mathrm{~h}$

- Metabolized 20\% by liver CYP 450
- Constipation

- Urinary retention

- Blurred vision

- Tachyarrhythmia
Antimuscarinic anticholinergic drugs
- $\quad$ Oral Fa $(\%) \approx 100 \%$

- $t_{\frac{t}{2}}=10.2 \pm 4.7 \mathrm{~h}$
- Dry mouth

- $\quad$ Blurred vision

- Abdominal discomfort

- Constipation

- Tachycardia

- Urinary retention

L-Dopa: Levodopa, Oral Fa (\%) absolute oral bioavailability, oral Fr (\%) relative oral bioavailability, transdermal $\mathrm{Fa}(\%)$ absolute transdermal bioavailability, $t_{\frac{t}{2}}$ : elimination half-life, DOPA decarboxylase: Aromatic L-amino acid decarboxylase, (COMT) catechol-O-methyl transferase enzyme, MAO B, monoamine oxidase enzyme, SC: subcutaneous, N/A: not applicable. 


\subsection{Challenges of PD Treatment}

Several limitations were observed when using L-Dopa for a long-term duration. For example, after only two years of exposure to L-Dopa, one-third of the patient described the development of various types of motor response oscillations and drug-induced dyskinesias, which may impede the benefits after initial treatment [144]. Earlier in 1990, in vitro studies demonstrated that high doses of L-Dopa can induce toxicity in dopaminergic neurons [145-147], which led some specialists to withdraw the recommendation for this drug [148]. However, pathological reports and autopsies from long-term exposed patients did not show evidence for substantia nigra degeneration [149-151].

L-Dopa's pharmacological and physiological properties increase the difficulty of its delivery [152]. Meanwhile, the main obstacle for optimizing the delivery of L-Dopa to the brain is the pathway the prodrug will have to take to pass the BBB efficiently, starting from its absorption site in the gastrointestinal tract to its conversion via aromatic decarboxylase and catechol-O-methyl transferase (COMT). These effects reduce L-Dopa biological $t_{\frac{t}{2}}$ and consequently it will lead to an insufficient delivery to the brain in addition to the conceived competition at the transport site to enter the brain [153]. Therefore, high doses of L-Dopa are required for an effective treatment which will be an object of debate since L-Dopa was not subjected to toxicological testing [152].

L-Dopa absorption from the gut is a subject of various limitations. First, L-Dopa is absorbed in the intestine and can be affected by the slow gastric emptying rate (GER) or constipation, which are the non-motor symptoms of PD [154]. Furthermore, delayed GER will reduce the bioavailability by inducing bacterial overgrowth, which may affect the rate at which L-Dopa reaches its absorption site. Second, since the chemical structure of L-Dopa is an alanine derivative, the amino acids from the diet interfere with the absorption of L-Dopa, hindering its absorption [155-158]. Third, it is estimated that only $1 \%$ of the administered drug will make it to the brain due to the ubiquitous distribution of DOPA decarboxylase that is spread in almost every tissue of the human body so that the dopamine will be degraded in multiple unwanted sites. Thus a significant proportion of the drug will no longer be available to pass the BBB [159]. Finally, in the last step in the delivery, a competition at the amino acids transporters will impede L-Dopa delivery to the substantia nigra [157].

\subsection{Therapeutic Aspects of EXOs in $P D$}

The blood-brain barrier (BBB) is a highly selective permeable membrane that thoroughly limits the transportation of large molecules and almost all tiny molecules from other organs to the brain. For this reason, various invasive techniques have been developed or under development to overwhelm the selectivity of the BBB, such as neurosurgery, the biochemical opening of the BBB, and different formulations of nanoparticles [160-162]. However, those techniques also have problems in terms of drug delivery, such as rapid drug clearance by the mononuclear phagocyte system (MPS). Several reports indicate that EXOs can cross the BBB and overcome the immune-special status to reduce drug clearance by MPS. More importantly, EXOs can spread and transport proteins and RNAs into the brain through intranasal, intravenous, intraperitoneal, and intracranial administration, which indicates the high flexibility and compatibility of EXOs-based drug delivery in treating CNS diseases [162-164]. Several drugs had been enveloped into EXOs for delivery uses in the past decade. Alvarez-Erviti et al. 2011 reported the delivery of small interfering RNAs (siRNAs) through EXOs into the mouse brain by tail vein injection [162]. Different therapeutic approaches are presented in Figure 4, detailed in Table 3, and discussed as follows. 
Table 3. Applications of exosomes in PD treatment.

\begin{tabular}{|c|c|c|c|c|c|c|}
\hline Cargo & $\begin{array}{l}\text { Vesicle Size } \\
\text { (nm) }\end{array}$ & Source & $\begin{array}{l}\text { Isolation } \\
\text { Method }\end{array}$ & Loading Method & Therapeutic Efficacy & Ref \\
\hline CAT & $100-200$ & $\begin{array}{c}\text { Mouse } \\
\text { macrophage }\end{array}$ & $\begin{array}{l}\text { Differential } \\
\text { centrifugation } \\
\text { followed by } \\
\text { filtration }\end{array}$ & $\begin{array}{l}\text { Incubation with or } \\
\text { without saponin, } \\
\text { freeze-thaw cycle, } \\
\text { sonication, or } \\
\text { extrusion }\end{array}$ & $\begin{array}{c}\text { Enhanced CAT } \\
\text { bioavailability in } \\
\text { neuronal cells, therefore, } \\
\text { increased therapeutic } \\
\text { efficacy and decreased } \\
\text { ROS level in the brain }\end{array}$ & [163] \\
\hline $\begin{array}{l}\text { CUR and } \\
\text { siRNA } \\
\text { molecules }\end{array}$ & 70 & $\operatorname{imDC}$ & $\begin{array}{l}\text { Differential } \\
\text { centrifugation } \\
\text { followed by } \\
\text { ultrafiltration } \\
\text { and passed } \\
\text { through a size } \\
\text { exclusion chro- } \\
\text { matography }\end{array}$ & Sonication & $\begin{array}{l}\text { Observed slowness in } \\
\text { movement speed, an } \\
\text { improvement in the time } \\
\text { to tip of the rod and an } \\
\text { immune suppressive } \\
\text { effect, an increase in Fox } \\
\text { p3 in CD } 4^{+} \text {T cells and a } \\
\text { decrease in the IL-22 and } \\
\text { IL-17 cytokines }\end{array}$ & [165] \\
\hline miR-188-3p & - & ADSC & \multirow{6}{*}{$\begin{array}{l}\text { Differential } \\
\text { centrifugation }\end{array}$} & $\begin{array}{l}\text { Culturing cells } \\
\text { with miR-188-3p- } \\
\text { overexpressed } \\
\text { EXOs }\end{array}$ & $\begin{array}{l}\text { Alleviated the damaged } \\
\text { substantia nigra and } \\
\text { suppressed the levels of } \\
\text { CDK5 and NLRP3 in the } \\
\text { PD mice model }\end{array}$ & [166] \\
\hline siRNA & - & BMDCs & & \multirow[b]{2}{*}{ Electroporation } & $\begin{array}{l}\text { A significant decrease in } \\
\text { total } \alpha \text {-syn mRNA and } \\
\text { protein level }\end{array}$ & [167] \\
\hline shRNA-MCs & - & $\begin{array}{l}\text { DCs } \\
\text { transfected } \\
\text { with RVG- } \\
\text { Lamp2b. }\end{array}$ & & & $\begin{array}{l}\text { Reduction in the } \alpha \text {-syn } \\
\text { aggregation and loss of } \\
\text { dopaminergic neurons }\end{array}$ & [168] \\
\hline L-Dopa & $40-200$ & $\begin{array}{l}\text { Blood of } \\
\text { Kunming } \\
\text { mice }\end{array}$ & & \multirow{3}{*}{ Incubation } & $\begin{array}{l}\text { Boosting the brain } \\
\text { delivery of DA }\end{array}$ & [169] \\
\hline $\begin{array}{c}\text { DNA } \\
\text { aptamers }\end{array}$ & 100 & $\begin{array}{l}\text { myc-RVG- } \\
\text { lamp2b }\end{array}$ & & & $\begin{array}{l}\text { PFF-induced insoluble } \\
\alpha \text {-syn aggregates were } \\
\text { reduced, therefore } \\
\text { reducing PD progression }\end{array}$ & [170] \\
\hline GDNF & $96.0 \pm 9.1$ & Macrophages & & & $\begin{array}{c}\text { Enabled GDNF to reach } \\
\text { CNS and consequently } \\
\text { induced a } \\
\text { neuroprotective effect, } \\
\text { and reduced } \\
\text { inflammation and levels } \\
\text { of activated microglia in } \\
\text { the targeted regions }\end{array}$ & [171] \\
\hline
\end{tabular}

BMDCs: Murine dendritic cells from bone marrow; ImDC: immature dendritic cell; ADSC: Adipose-derived stem cell; DCs: Primary dendritic cells; RVG: Rabies virus glycoprotein; Lamp2b: lysosomal associated membrane protein-2; Myc-RVG-lamp2b: Mice rabies virus glycoprotein-lysosomal-associated membrane protein-2; PFF: performed fibrils; GDNF: Glial cell line-derived neurotrophic factor.

\subsubsection{Drug-Loaded EXOs}

To date, there are no curative approaches that halt the course of PD. Only the treatment that temporarily replaces the missing neurotransmitters is currently available. Most of what is known as a difficulty for current PD treatments resides in the inability to cross the BBB. The drug can be loaded to EXOs to curtail these concerns, based on their ability to mediate the neuronal communication in the CNS and pass through the BBB [172]. EXOs 
could be harnessed to deliver CNS-acting drugs to treat and alleviate PD symptoms since they can adhere to the specified cell surface and release their cargoes [29,173-175].

As mentioned previously, PD occurs when the dopaminergic neurons in the substantia nigra pars compacta have been damaged, and consequently, the DA level decreases [176]. Therefore, DA administration to the brain to compensate for the reduction in DA level is proposed, but the limitation is to cross the BBB in the therapeutic dose. Thus, L-Dopa shows a promising therapeutic action because it is converted into the parent drug in the brain [177].

Even though L-Dopa can reach the brain, delivering a sufficient amount to the targeted regions is challenging. Unfortunately, a small amount of L-Dopa can pass to the brain due to the destruction of L-Dopa in plasma by the decarboxylase enzyme [178]. Thus, researchers interest increase in drug delivery systems such as ligand-modified nanoparticles [179], micelles [180], mesoporous nanoparticles [181], dendrimers [182], and EXOs [169]. These systems can allow the direct use of DA in the brain. Compared to EXOs, ligand-modified nanoparticles, micelles, and dendrimers show modest results to pass through the BBB [182]. However, EXOs have many ways to override this obstacle, and they can cross the BBB and reach the drug to its target. The proposed underlying mechanism is that EXOs can cross through the endothelial cells by "Jumping", undergo transcytosis, and eventually release their content [183]. Another suggested mechanism is that EXOs can break down the vascular endothelial barrier in the BBB to enhance the penetration [184].
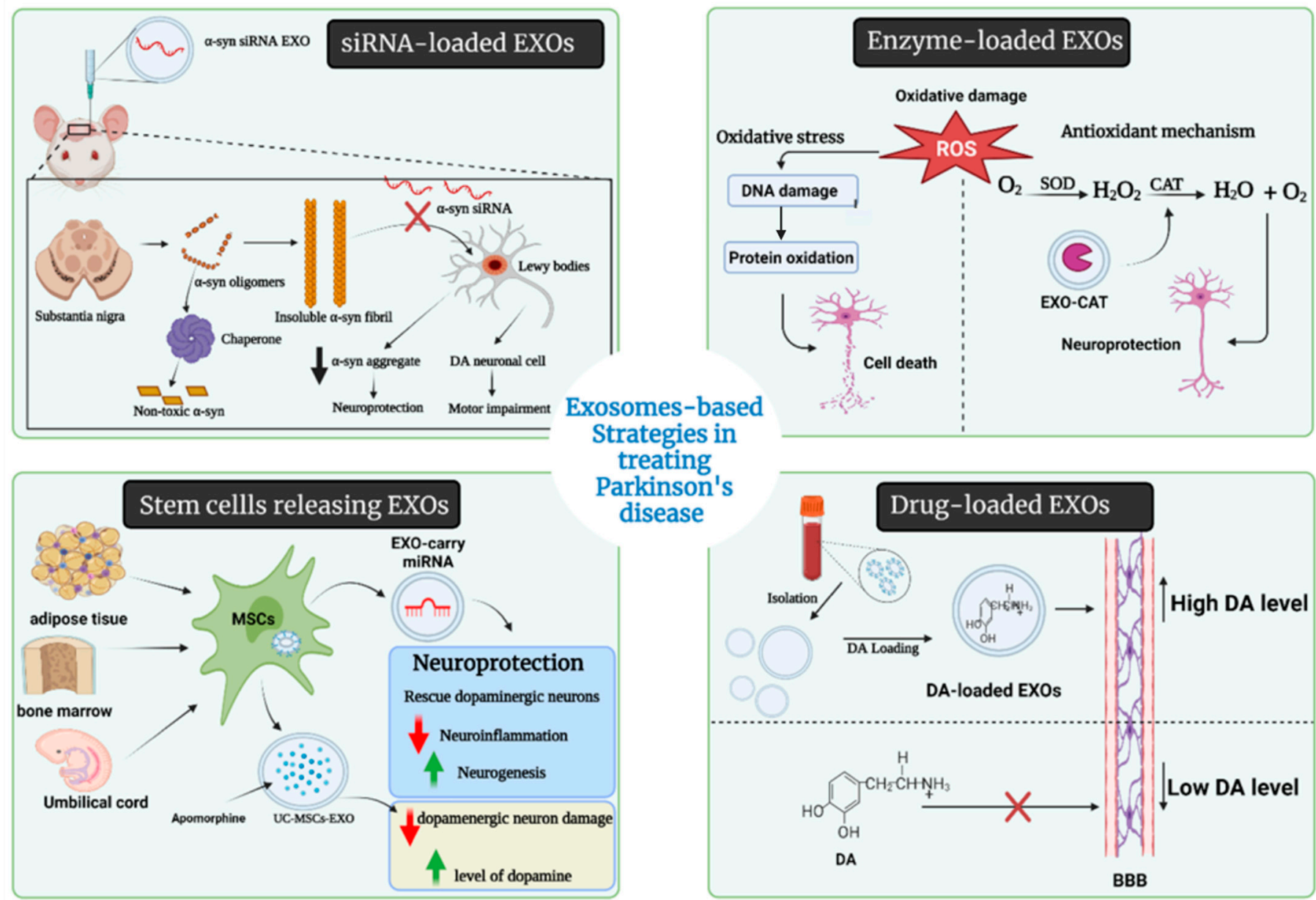
Strategies in treating

Parkinson's disease

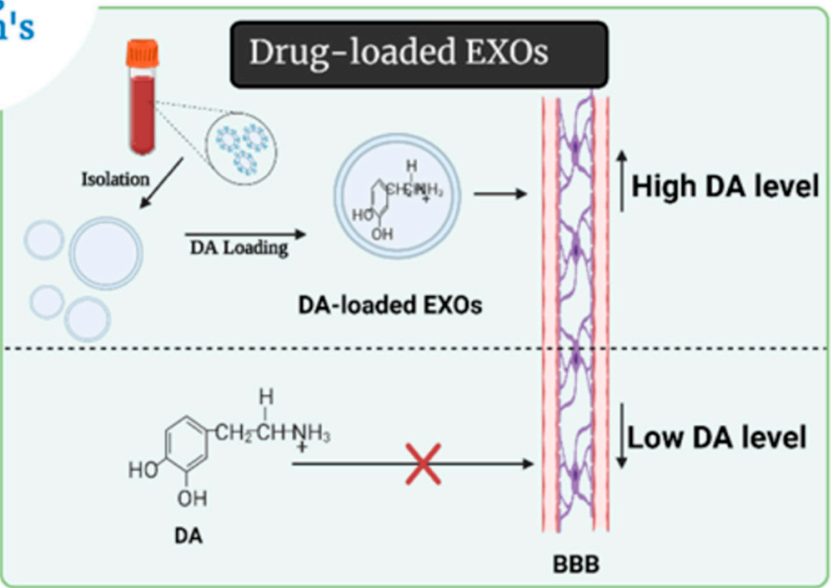

Figure 4. Therapeutic approaches of EXOs in PD.

Moreover, transferrin receptor (TFR) is highly expressed by brain capillary endothelial cells forming the BBB and is therefore considered a potential target for brain drug delivery [185]. Based on the transferrin-TFR interaction, EXOs can bind to the transferring 
receptors and get to the brain. Qu et al. collected blood EXOs from a mice model. Then, they encapsulated DA into these vesicles, and the obtained formulation was systematically administered to the mouse model of PD [169]. The results showed a significant decrease in the amphetamine-induced rotation test compared to the control group. This test tool is used to predict the extent of motor impairment in PD [186]. In addition, the amount of DA in lesioned striatum significantly increased compared with the control [169]. The used EXOs in this experiment were blood derived, specifically from reticulocytes. The use of blood EXOs as drug carriers with appropriate loading efficacy is considered a potential future candidate to treat PD.

Additionally, quercetin, a plant flavonol from the flavonoid group, is considered a supplemental therapy for PD [187]. However, this flavonoid has poor brain targeting activity and low bioavailability, limiting its effect in lesioned brain areas [188]. Quercetin loading into EXOs (EXO-Que) showed better results in other NDDs, including AD, which dictates future research on flavonoid-loaded EXOs in PD.

\subsubsection{Enzyme-Loaded EXOs}

The unmet medical need for PD treatment is undoubtedly known for every medical practitioner. To solve this dilemma, scientists used enzymes that might interfere in the pathological cascade for PD, such as catalase (CAT), labeled it to EXOs, and considerable results were obtained. CAT-loaded EXOs is a novel therapeutic approach that has been studied by Haney et al. subjected to in vitro and in vivo studies [163]. CAT is a large protein referred to as a major antioxidant enzyme, and it neutralizes the deleterious effects of reactive oxygen species (ROS), which is the major component in the cascade of PD pathological mechanisms [189].

Throughout Haney et al.'s experiments, CAT was the payload of EXOs and was incorporated into these vesicles using different methods to test which one was most suitable as a drug loading technique. They used sonication, incubation at room temperature (RT), freeze/thaw cycles, or extrusion procedures. The obtained EXO-CAT formulations using sonication and extrusion showed the highest catalytic activity, followed by those obtained by freeze/thaw cycles and then the incubation at RT. Interestingly, the results were optimistic and proved the extraordinary ability of these tiny vesicles to reach the CNS, interact with the targeted neurons and deliver the incorporated CAT. Furthermore, CAT molecules showed an efficient deactivating effect on ROS; thus, it provided a prompt neuroprotective ability in PD. The experiment by Haney et al. showed the most promising results after sonication or extrusion [163].

\subsubsection{EXOs-Loaded Short Hairpin (sh-), si-, and miRNA Molecules}

The degeneration of nigrostriatal dopaminergic neurons leads to the accumulation of intracellular molecules known as Lewy bodies, which are composed of a spherical matter called $\alpha$-syn [7,190]. Thus, decreasing $\alpha$-syn expression through gene knockdown may be a responsible approach for treating PD. Silencing $\alpha$-syn transcription by siRNA exhibits a priority in the field of gene therapy by a phenomenon referred to as RNA interference (RNAi) [191].

A study by Lewis et al. reported that infusion of modified siRNA against $\alpha$-syn into the hippocampus of normal mice downregulated the $\alpha$-syn over 14 days [192]. Although promising results were documented on the application of siRNAs, their effect on cerebral regions was hampered because of the difficulty of targeting specific tissues or cell types, immunogenicity, and a short-term gene downregulation lasting for 3-7 days after injection [167].

An untapped effective siRNA delivery might be provided using natural core-shell EXOs because they could cross the BBB [164].

From the genetic perspective, siRNA-loaded rabies virus glycoprotein-EXOs (RVGEXOs) were reported as a potential silencer for $\alpha$-syn mRNA expression in the substantia nigra, exhibiting a significant effect in treating PD. The siRNA-loaded EXOs showed 
less efficacy in reducing ROS levels in PD-derived tissues than curcumin (CUR) since CUR-loaded EXOs had neuroprotective properties and could readily decrease the $\alpha$-syn aggregates [193]. For this reason, a combination of both treatments might synergistically reduce the $\alpha$-syn cytotoxicity on the nigrostriatal dopaminergic neurons.

Other non-coding RNA had been loaded to EXOs and showed modulatory disease attenuation effects $[162,166,194,195]$. Utilizing shRNA carried on adeno-associated virus inhibited the expression of endogenous $\alpha$-syn [194] when loaded to which were doublestranded DNA vectors (minicircles; MCs). This exosomal platform expanded the gene silencing period to over seven weeks, which was longer, making it applicable for chronic PD cases and reducing the injection frequency and cost for patient satisfaction [168]. Izco et al. extracted the RVG-EXOs from primary dendritic cells and loaded them with shRNAMCs [168]. The in vivo results were quite promising, with a potential decrease in $\alpha$-syn protein levels over a prolonged period. However, the systemic injection into a mouse failed, as described by the results after 30 days of follow-up. The results showed no significant changes in the $\alpha$-syn mRNA levels in the ipsilateral or contralateral brain regions and showed an observed significant increase in the $\alpha$-syn protein levels in the striatum. Nevertheless, after 90 days, positive responses in the substantia nigra pars compacta, and other brain regions were observed, which reflected the potential action of the RVG-EXOs delivered shRNA-MCs on a longer duration.

The pathological hallmarks of PD correlate with miRNA's expression level, which is abundantly expressed in the CSF of PD patients and constitutes a protective environment for genetic materials. EXOs-based miRNA delivery exhibits the possibility to alter BBB integrity. Thereafter, the administration of EXOs with a high abundance of specific miRNAs may become a next-generation miRNA-based therapy that develops from the conventional direct application of miRNAs as therapeutic drugs. Currently, two different methods have been embraced to explore the potential therapeutic application of exosomal miRNAs as drugs to treat NDDs. The first one is to administrate EXOs containing valuable therapeutic miRNAs directly. At the same time, an alternative approach for in vivo studies is to package selected miRNAs that eliminate disease-associated genes or improve neurodegenerative factors into EXOs [162]. In the case of PD, treatment with miR-188-3p-enriched EXOs can suppress autophagy and pyroptosis by targeting the core molecules of inflammasome CDK5 and NLRP3 [166]. miR-7 is another miRNA whose expression allows normal development and neurogenesis in the CNS and keeps $\alpha$-syn at the physiological level [195]. Moreover, miR$30 \mathrm{a}-5 \mathrm{p}$ is a factor in the pathogenesis of PD by regulating ubiquitin-mediated degradation of glutamate transporter 1 , and it ameliorates the motor deficits and the pathological consequences [196]. Thereby, loading these molecules into EXOs is a nuanced approach, though it is still in its infancy since it harbors several beneficial effects and deserves to be studied in future experimental designs and clinical trials [197].

\subsubsection{EXOs as Nanoscavengers}

A biological nansoscavenger is a molecule that targets toxins in specific regions and induces a deterrent effect. From this concept, EXOs can be regarded as nanoscavengers carrying different cargos such as RNA, and miRNA drugs such as quercetin and CUR, and even enzymes such as neprilysin and insulin-degrading enzyme. EXOs succeed in drawing an in-depth look for their future usage in clinical studies for AD [198]. Similarly, nanoscavenger in PD may pave the way for future treatment choices.

More recently, Liu et al. designed a core-shell hybrid system called a nanoscavenger by immature dendritic cells (imDC)-derived EXOs loaded with hydrophobic CUR and hydrophilic siRNA molecules. These molecules were combined into one shell using the phenylboronic acid-poly(2-(dimethylamino) ethyl acrylate) nanoparticle. The nanoscavenger effectively delivered the gene-chem drug to the targeted brain regions [165].

After the tenth administration, the results showed a significant slow movement speed and reduced the time needed to tip the rod in the treated mice. Moreover, an immunosuppressive effect was demonstrated after nanoscavenger treatment. Furthermore, an 
increase in Fox p3 in CD4 $4^{+} \mathrm{T}$ cells and a decrease in the IL-22 and IL-17 cytokines were observed. In addition to the reported efficacy, the safety of this treatment was tested in the mice model, and no toxicity or induced organ damage was revealed. The results from the experiment are promising, knowing that it is the first study to combine CUR with the component siRNA into one system using the core EXOs to target $\alpha$-syn.

\subsection{Stem Cells-Derived EXOs}

Mesenchymal stem cells (MSCs) are multipotent progenitor cells that can be isolated from several tissues, including bone marrow (BM), adipose tissue, umbilical cord (UC), and placenta, because of their anti-inflammatory, anti-apoptotic and immunomodulatory properties. MSCs have been used in clinical trials for various disorders, including NDDs [199,200]. In addition, EXOs derived from MSCs have been considered effective for treating various pathological conditions, including CNS disorder, and their ability to rescue dopaminergic neurons in neurotoxic synthetic organic compound 6-hydroxydopamine (6-OHDA) mice models of PD. Furthermore, MSCs-derived EXOs provide a potential PD treatment since they carry beneficial miRNAs and interact with neuronal cells to decrease neuroinflammation and stimulate neurogenesis in PD animal models [201].

EXOs isolated from various cells can be manipulated to target specific neurons and brain regions, making them potentially therapeutic for PD and other NDDs [202]. For example, EXOs derived from UC-MSCs enriched apomorphine-produced asymmetric rotation by lowering the damage of dopaminergic neurons in the substantia nigra and enhancing DA levels in the striatum [203].

\section{Conclusions}

As a nano-vesicular system, EXOs could be vehicles for different molecules, including proteins, nucleic acids, miRNAs, and even drugs; therefore, they attracted great interest as diagnostic and therapeutic players in PD. These nano-vesicles possess a role in PD propagation by spreading misfolded $\alpha$-syn through a cell-to-cell communication-based mechanism. Compared to other drug delivery systems, the uniqueness of EXOs lies in their ability to penetrate the BBB and the low immunogenicity of the natural vesicles derived from cell membranes. Consequently, a future outlook to applying EXOs in delivering various cargos, including miRNAs, shRNA, siRNAs, enzymes, and drugs, is an intriguing approach. Isolated EXOs from PD patients have led to identifying novel biomarkers for PD, a promising prospective diagnostic and prognostic tool for this disease. However, EXOs were detrimental in PD patients; their pros can be exploited to treat NDDs.

Author Contributions: This work was carried out in collaboration with all authors. All authors have read and agreed to the published version of the manuscript.

Funding: This research received no external funding.

Institutional Review Board Statement: Not applicable.

Informed Consent Statement: Not applicable.

Data Availability Statement: No new data were created or analyzed in this study. Data sharing is not applicable to this article.

Acknowledgments: The authors wish to extend their sincere thanks to Fakhr El-Din Soliman Ghazy (Dept. of Pharmaceutics, Faculty of Pharmacy, Zagazig University) and Mohamed A. Marzouk (Dept. of Organic Chemistry, Faculty of Pharmacy, Zagazig University). In addition, the authors are thankful for biorender.com for creating the figures and graphical abstract with license number (ZD23EC4NK3, YH23EC4BNK, NN23EC41EY, OE22XGKQLT, CC22X0YKR5).

Conflicts of Interest: The authors declare no conflict of interest. 


\section{References}

1. Emard, J.F.; Thouez, J.P.; Gauvreau, D. Neurodegenerative Diseases and Risk Factors: A Literature Review. Soc. Sci. Med. 1995, 40, 847-858. Available online: https:/ / www.sciencedirect.com/science/article/pii/027795369400138J (accessed on 15 July 2021). [CrossRef]

2. Ingenta Connect. Current Limitations in the Treatment of Parkinson's and Alzheimer. Available online: https://www. ingentaconnect.com/content/ben/cmc/2018/00000025/00000041/art00011 (accessed on 15 July 2021).

3. Katzenschlager, R.; Lees, A.J. Treatment of Parkinson's Disease: Levodopa as the First Choice. J. Neurol. 2002, 249 (Suppl. 2), II19-II24. [CrossRef]

4. Bartel, W.P.; Van Laar, V.S.; Burton, E.A. Chapter 23-Parkinson's Disease. In Behavioral and Neural Genetics of Zebrafish; Gerlai, R.T., Ed.; Academic Press: Cambridge, MA, USA, 2020; pp. 377-412. ISBN 978-0-12-817528-6.

5. Sonne, J.; Reddy, V.; Beato, M.R. Neuroanatomy, Substantia Nigra. In StatPearls; StatPearls Publishing: Treasure Island, FL, USA, 2021.

6. Veljkovic, E.; Xia, W.; Phillips, B.; Wong, E.T.; Ho, J.; Oviedo, A.; Hoeng, J.; Peitsch, M. (Eds.) Chapter 1—Parkinson's Disease. In Nicotine and Other Tobacco Compounds in Neurodegenerative and Psychiatric Diseases; Academic Press: Cambridge, MA, USA, 2018; pp. 3-12. ISBN 978-0-12-812922-7.

7. Reisberg, B. Dementia: Overview. In International Encyclopedia of the Social \& Behavioral Sciences; Smelser, N.J., Baltes, P.B., Eds.; Pergamon: Oxford, UK, 2001; pp. 3389-3396. ISBN 978-0-08-043076-8.

8. Gandhi, K.R.; Saadabadi, A. Levodopa (L-Dopa). In StatPearls; StatPearls Publishing: Treasure Island, FL, USA, 2021.

9. Schulz-Schaeffer, W.J. The Synaptic Pathology of $\alpha$-Synuclein Aggregation in Dementia with Lewy Bodies, Parkinson's Disease and Parkinson's Disease Dementia. Acta Neuropathol. 2010, 120, 131-143. [CrossRef]

10. Bahbah, E.I.; Ghozy, S.; Attia, M.S.; Negida, A.; Emran, T.B.; Mitra, S.; Albadrani, G.M.; Abdel-Daim, M.M.; Uddin, M.; SimalGandara, J. Molecular Mechanisms of Astaxanthin as a Potential Neurotherapeutic Agent. Mar. Drugs 2021, 19, 201. [CrossRef] [PubMed]

11. Kumari, U.; Tan, E.K. LRRK2 in Parkinson's Disease: Genetic and Clinical Studies from Patients. FEBS J. 2009, $276,6455-6463$. [CrossRef] [PubMed]

12. Li, J.-Q.; Tan, L.; Yu, J.-T. The Role of the LRRK2 Gene in Parkinsonism. Mol. Neurodegener. 2014, 9, 47. [CrossRef] [PubMed]

13. Doyle, L.M.; Wang, M.Z. Overview of Extracellular Vesicles, Their Origin, Composition, Purpose, and Methods for Exosome Isolation and Analysis. Cells 2019, 8, 727. [CrossRef] [PubMed]

14. Martins, T.S.; Trindade, D.; Vaz, M.; Campelo, I.; Almeida, M.; Trigo, G.; da Cruz e Silva, O.A.B.; Henriques, A.G. Diagnostic and Therapeutic Potential of Exosomes in Alzheimer's Disease. J. Neurochem. 2021, 156, 162-181. [CrossRef]

15. Frühbeis, C.; Fröhlich, D.; Kuo, W.P.; Krämer-Albers, E. Extracellular Vesicles as Mediators of Neuron-Glia Communication. Front. Cell. Neurosci. 2013, 7, 182. Available online: https://www.frontiersin.org/articles/10.3389/fncel.2013.00182/full? utm_source=newsletter\&utm_medium=web\&utm_campaign=Neuroscience-w46-2013 (accessed on 15 July 2021). [CrossRef] [PubMed]

16. Krämer-Albers, E.-M.; Bretz, N.; Tenzer, S.; Winterstein, C.; Möbius, W.; Berger, H.; Nave, K.-A.; Schild, H.; Trotter, J. Oligodendrocytes Secrete Exosomes Containing Major Myelin and Stress-Protective Proteins: Trophic Support for Axons? Proteom. Clin. Appl. 2007, 1, 1446-1461. [CrossRef]

17. Li, W.; Li, C.; Zhou, T.; Liu, X.; Liu, X.; Li, X.; Chen, D. Role of Exosomal Proteins in Cancer Diagnosis. Mol. Cancer 2017, 16, 145. [CrossRef] [PubMed]

18. Ma, Y.-S.; Yang, X.-L.; Xin, R.; Liu, J.-B.; Fu, D. Power and Promise of Exosomes as Clinical Biomarkers and Therapeutic Vectors for Liquid Biopsy and Cancer Control. Biochim. Biophys. Acta (BBA)-Rev. Cancer 2021, 1875, 188497. [CrossRef]

19. Si, X.-L.; Fang, Y.-J.; Li, L.-F.; Gu, L.-Y.; Yin, X.-Z.; Tian, J.; Yan, Y.-P.; Pu, J.-L.; Zhang, B.-R. From Inflammasome to Parkinson's Disease: Does the NLRP3 Inflammasome Facilitate Exosome Secretion and Exosomal Alpha-Synuclein Transmission in Parkinson's Disease? Exp. Neurol. 2021, 336, 113525. [CrossRef]

20. Maguire, G. Chapter 7-Exosomes: Smart Nanospheres for Drug Delivery Naturally Produced by Stem Cells. In Fabrication and Self-Assembly of Nanobiomaterials; Grumezescu, A.M., Ed.; William Andrew Publishing: Norwich, NY, USA, 2016; pp. 179-209. ISBN 978-0-323-41533-0.

21. Patil, S.M.; Sawant, S.S.; Kunda, N.K. Exosomes as Drug Delivery Systems: A Brief Overview and Progress Update. Eur. J. Pharm. Biopharm. 2020, 154, 259-269. [CrossRef]

22. Rahman, M.M.; Ferdous, K.S.; Ahmed, M. Emerging Promise of Nanoparticle-Based Treatment for Parkinson's Disease. Biointerface Res. Appl. Chem. 2020, 10, 7135-7151. [CrossRef]

23. Parnham, M.J.; Wetzig, H. Toxicity Screening of Liposomes. Chem. Phys. Lipids 1993, 64, 263-274. [CrossRef]

24. Zielińska, A.; Carreiró, F.; Oliveira, A.M.; Neves, A.; Pires, B.; Venkatesh, D.N.; Durazzo, A.; Lucarini, M.; Eder, P.; Silva, A.M.; et al. Polymeric Nanoparticles: Production, Characterization, Toxicology and Ecotoxicology. Molecules 2020, 25, 3731. [CrossRef]

25. Antimisiaris, S.G.; Mourtas, S.; Marazioti, A. Exosomes and Exosome-Inspired Vesicles for Targeted Drug Delivery. Pharmaceutics 2018, 10, 218. [CrossRef] [PubMed]

26. Liu, X.; Han, M.; Xu, J.; Geng, S.; Zhang, Y.; Ye, X.; Gou, J.; Yin, T.; He, H.; Tang, X. Asialoglycoprotein Receptor-Targeted Liposomes Loaded with a Norcantharimide Derivative for Hepatocyte-Selective Targeting. Int. J. Pharm. 2017, 520, 98-110. [CrossRef] [PubMed] 
27. Zhang, Y.; Liu, Y.; Liu, H.; Tang, W.H. Exosomes: Biogenesis, Biologic Function and Clinical Potential. Cell Biosci. 2019, 9, 1-18. Available online: https:/ / cellandbioscience.biomedcentral.com/articles/10.1186/s13578-019-0282-2 (accessed on 25 November 2021). [CrossRef]

28. Abels, E.R.; Breakefield, X.O. Introduction to Extracellular Vesicles: Biogenesis, RNA Cargo Selection, Content, Release, and Uptake. Cell. Mol. Neurobiol. 2016, 36, 301-312. [CrossRef]

29. Ha, D.; Yang, N.; Nadithe, V. Exosomes as Therapeutic Drug Carriers and Delivery Vehicles across Biological Membranes: Current Perspectives and Future Challenges. Acta Pharm. Sin. B 2016, 6, 287-296. [CrossRef]

30. De Toro, J.; Herschlik, L.; Waldner, C.; Mongini, C. Emerging Roles of Exosomes in Normal and Pathological Conditions: New Insights for Diagnosis and Therapeutic Applications. Front. Immunol. 2015, 6, 203. [CrossRef] [PubMed]

31. Dai, J.; Su, Y.; Zhong, S.; Cong, L.; Liu, B.; Yang, J.; Tao, Y.; He, Z.; Chen, C.; Jiang, Y. Exosomes: Key Players in Cancer and Potential Therapeutic Strategy. Signal Transduct. Target. Ther. 2020, 5, 145. [CrossRef] [PubMed]

32. Gurunathan, S.; Kang, M.-H.; Kim, J.-H. A Comprehensive Review on Factors Influences Biogenesis, Functions, Therapeutic and Clinical Implications of Exosomes. Int. J. Nanomed. 2021, 16, 1281-1312. [CrossRef] [PubMed]

33. Record, M.; Silvente-Poirot, S.; Poirot, M.; Wakelam, M.J.O. Extracellular Vesicles: Lipids as Key Components of Their Biogenesis and Functions. J. Lipid Res. 2018, 59, 1316-1324. [CrossRef] [PubMed]

34. Huang, X.; Yuan, T.; Tschannen, M.; Sun, Z.; Jacob, H.; Du, M.; Liang, M.; Dittmar, R.L.; Liu, Y.; Liang, M.; et al. Characterization of Human Plasma-Derived Exosomal RNAs by Deep Sequencing. BMC Genom. 2013, 14, 1-14. Available online: https: //bmcgenomics.biomedcentral.com/articles/10.1186/1471-2164-14-319 (accessed on 25 November 2021). [CrossRef] [PubMed]

35. Mittelbrunn, M.; Gutiérrez-Vázquez, C.; Villarroya-Beltri, C.; González, S.; Sánchez-Cabo, F.; González, M.Á.; Bernad, A.; Sánchez-Madrid, F. Unidirectional Transfer of MicroRNA-Loaded Exosomes from T Cells to Antigen-Presenting Cells. Nat. Commun. 2011, 2, 1-10. Available online: https:/ / www.nature.com/articles/ncomms1285 (accessed on 25 November 2021). [CrossRef]

36. Hewson, C.; Capraro, D.; Burdach, J.; Whitaker, N.; Morris, K.V. Extracellular Vesicle Associated Long Non-Coding RNAs Functionally Enhance Cell Viability. Noncoding RNA Res. 2016, 1, 3-11. [CrossRef]

37. Meng, S.; Zhou, H.; Feng, Z.; Xu, Z.; Tang, Y.; Li, P.; Wu, M. CircRNA: Functions and Properties of a Novel Potential Biomarker for Cancer. Mol. Cancer 2017, 16, 94. [CrossRef] [PubMed]

38. Li, P.; Kaslan, M.; Lee, S.H.; Yao, J.; Gao, Z. Progress in Exosome Isolation Techniques. Theranostics 2017, 7, 789-804. [CrossRef] [PubMed]

39. Linares, R.; Tan, S.; Gounou, C.; Arraud, N.; Brisson, A.R. High-Speed Centrifugation Induces Aggregation of Extracellular Vesicles. J. Extracell. Vesicles 2015, 4, 29509. [CrossRef] [PubMed]

40. Sidhom, K.; Obi, P.O.; Saleem, A. A Review of Exosomal Isolation Methods: Is Size Exclusion Chromatography the Best Option? Int. J. Mol. Sci. 2020, 21, 6466. [CrossRef] [PubMed]

41. Exosomes in Parkinson Disease-Journal of Neurochemistry-Wiley Online Library. 2021. Available online: https:/ / onlinelibrary. wiley.com/doi/full/10.1111/jnc.15288 (accessed on 4 September 2021).

42. Alvarez-Erviti, L.; Seow, Y.; Schapira, A.H.; Gardiner, C.; Sargent, I.L.; Wood, M.J.A.; Cooper, J.M. Lysosomal Dysfunction Increases Exosome-Mediated Alpha-Synuclein Release and Transmission. Neurobiol. Dis. 2011, 42, 360-367. [CrossRef]

43. Theillet, F.-X.; Binolfi, A.; Bekei, B.; Martorana, A.; Rose, H.M.; Stuiver, M.; Verzini, S.; Lorenz, D.; van Rossum, M.; Goldfarb, D.; et al. Structural Disorder of Monomeric $\alpha$-Synuclein Persists in Mammalian Cells. Nature 2016, 530, 45-50. Available online: https:/ / www.nature.com/articles/nature16531 (accessed on 25 November 2021). [CrossRef]

44. Kumari, P.; Ghosh, D.; Vanas, A.; Fleischmann, Y.; Wiegand, T.; Jeschke, G.; Riek, R.; Eichmann, C. Structural Insights into

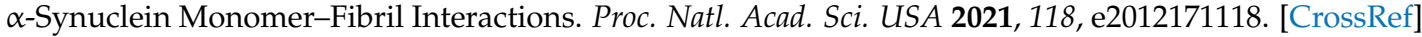

45. Vandendriessche, C.; Bruggeman, A.; Van Cauwenberghe, C.; Vandenbroucke, R.E. Extracellular Vesicles in Alzheimer's and Parkinson's Disease: Small Entities with Large Consequences. Cells 2020, 9, 2485. [CrossRef]

46. Guo, M.; Wang, J.; Zhao, Y.; Feng, Y.; Han, S.; Dong, Q.; Cui, M.; Tieu, K. Microglial Exosomes Facilitate $\alpha$-Synuclein Transmission in Parkinson's Disease. Brain 2020, 143, 1476-1497. Available online: https://academic.oup.com/brain/article/143/5/1476/582 7587? login=true (accessed on 4 September 2021). [CrossRef]

47. Fan, R.Z.; Guo, M.; Luo, S.; Cui, M.; Tieu, K. Exosome Release and Neuropathology Induced by $\alpha$-Synuclein: New Insights into Protective Mechanisms of Drp1 Inhibition. Acta Neuropathol. Commun. 2019, 7, 184. [CrossRef]

48. Desplats, P.; Lee, H.-J.; Bae, E.-J.; Patrick, C.; Rockenstein, E.; Crews, L.; Spencer, B.; Masliah, E.; Lee, S.-J. Inclusion Formation and Neuronal Cell Death through Neuron-to-Neuron Transmission of $\alpha$-Synuclein. Proc. Natl. Acad. Sci. USA 2009, 106, 13010-13015. [CrossRef]

49. Biological Properties of Extracellular Vesicles and Their Physiological Functions. Available online: https://www.tandfonline. com/doi/full/10.3402/jev.v4.27066 (accessed on 4 September 2021).

50. Théry, C.; Witwer, K.W.; Aikawa, E.; Alcaraz, M.J.; Anderson, J.D.; Andriantsitohaina, R.; Antoniou, A.; Arab, T.; Archer, F.; Atkin-Smith, G.K.; et al. Minimal Information for Studies of Extracellular Vesicles 2018 (MISEV2018): A Position Statement of the International Society for Extracellular Vesicles and Update of the MISEV2014 Guidelines. J. Extracell. Vesicles 2018, 7, 1535750. [CrossRef] [PubMed]

51. Chang, C.; Lang, H.; Geng, N.; Wang, J.; Li, N.; Wang, X. Exosomes of BV-2 Cells Induced by Alpha-Synuclein: Important Mediator of Neurodegeneration in PD. Neurosci. Lett. 2013, 548, 190-195. [CrossRef] [PubMed] 
52. Xia, Y.; Zhang, G.; Han, C.; Ma, K.; Guo, X.; Wan, F.; Kou, L.; Yin, S.; Liu, L.; Huang, J.; et al. Microglia as Modulators of Exosomal Alpha-Synuclein Transmission. Cell Death Dis. 2019, 10, 174. [CrossRef]

53. Grey, M.; Dunning, C.J.; Gaspar, R.; Grey, C.; Brundin, P.; Sparr, E.; Linse, S. Acceleration of $\alpha$-Synuclein Aggregation by Exosomes. J. Biol. Chem. 2015, 290, 2969-2982. [CrossRef] [PubMed]

54. Emmanouilidou, E.; Melachroinou, K.; Roumeliotis, T.; Garbis, S.D.; Ntzouni, M.; Margaritis, L.H.; Stefanis, L.; Vekrellis, K. Cell-Produced $\alpha$-Synuclein Is Secreted in a Calcium-Dependent Manner by Exosomes and Impacts Neuronal Survival. J. Neurosci. 2010, 30, 6838-6851. [CrossRef] [PubMed]

55. Poehler, A.-M.; Xiang, W.; Spitzer, P.; May, V.E.L.; Meixner, H.; Rockenstein, E.; Chutna, O.; Outeiro, T.F.; Winkler, J.; Masliah, E.; et al. Autophagy Modulates SNCA/ $\alpha$-Synuclein Release, Thereby Generating a Hostile Microenvironment. Autophagy 2014, 10, $2171-2192$. [CrossRef] [PubMed]

56. Lee, H.-J.; Cho, E.-D.; Lee, K.W.; Kim, J.-H.; Cho, S.-G.; Lee, S.-J. Autophagic failure promotes the exocytosis and intercellular transfer of $\alpha$-synuclein. Exp. Mol. Med. 2013, 45, e22. [CrossRef] [PubMed]

57. Hirsch, E.C.; Hunot, S. Neuroinflammation in Parkinson's Disease: A Target for Neuroprotection? Lancet Neurol. 2009,8 , 382-397. [CrossRef]

58. Brück, D.; Wenning, G.K.; Stefanova, N.; Fellner, L. Glia and Alpha-Synuclein in Neurodegeneration: A Complex Interaction Neurobiol. Dis. 2016, 85, 262-274. [CrossRef] [PubMed]

59. Sarkar, S.; Dammer, E.B.; Malovic, E.; Olsen, A.L.; Raza, S.A.; Gao, T.; Xiao, H.; Oliver, D.L.; Duong, D.; Joers, V.; et al. Molecular Signatures of Neuroinflammation Induced by ASynuclein Aggregates in Microglial Cells. Front. Immunol. 2020, 11, 33. [CrossRef] [PubMed]

60. Clarke, C.E.; Moore, A.P. Parkinson's Disease. Am. Fam. Phys. 2007, 75, 1045. [CrossRef] [PubMed]

61. Cao, X.-Y.; Lu, J.-M.; Zhao, Z.-Q.; Li, M.-C.; Lu, T.; An, X.-S.; Xue, L.-J. MicroRNA Biomarkers of Parkinson's Disease in Serum Exosome-like Microvesicles. Neurosci. Lett. 2017, 644, 94-99. [CrossRef] [PubMed]

62. Parkinson's Disease-Clinical Evidence Handbook-American Family Physician. Available online: https://www.aafp.org/afp/ 2007/0401/p1045.html (accessed on 4 August 2021).

63. Biomarkers in Parkinson's Disease: An Update. Current Opinion in Neurology. Available online: https://journals.lww.com/coneurology/Abstract/2012/08000/Biomarkers_in_Parkinson_s_disease_an_update.12.aspx (accessed on 4 August 2021).

64. Upadhya, R.; Zingg, W.; Shetty, S.; Shetty, A.K. Astrocyte-Derived Extracellular Vesicles: Neuroreparative Properties and Role in the Pathogenesis of Neurodegenerative Disorders. J. Control. Release 2020, 323, 225-239. [CrossRef] [PubMed]

65. Zheng, T.; Zhang, Z. Activated Microglia Facilitate the Transmission of $\alpha$-Synuclein in Parkinson's Disease. Neurochem. Int. 2021, 148, 105094. [CrossRef] [PubMed]

66. Picca, A.; Guerra, F.; Calvani, R.; Bucci, C.; Lo Monaco, M.R.; Bentivoglio, A.R.; Landi, F.; Bernabei, R.; Marzetti, E. MitochondrialDerived Vesicles as Candidate Biomarkers in Parkinson's Disease: Rationale, Design and Methods of the EXosomes in PArkiNson Disease (EXPAND) Study. Int. J. Mol. Sci. 2019, 20, 2373. [CrossRef] [PubMed]

67. Damme, M.; Suntio, T.; Saftig, P.; Eskelinen, E.L. Autophagy in Neuronal Cells: General Principles and Physiological and Pathological Functions. Acta Neuropathol. 2015, 129, 337-362. [CrossRef] [PubMed]

68. Fader, C.M.; Sánchez, D.; Furlán, M.; Colombo, M.I. Induction of Autophagy Promotes Fusion of Multivesicular Bodies with Autophagic Vacuoles in K562 Cells. Traffic 2008, 9, 230-250. [CrossRef]

69. Baixauli, F.; López-Otín, C.; Mittelbrunn, M. Exosomes and Autophagy: Coordinated Mechanisms for the Maintenance of Cellular Fitness. Front. Immunol. 2014, 5, 403. [CrossRef] [PubMed]

70. Betarbet, R.; Sherer, T.B.; MacKenzie, G.; Garcia-Osuna, M.; Panov, A.V.; Greenamyre, J.T. Chronic Systemic Pesticide Exposure Reproduces Features of Parkinson's Disease. Nat. Neurosci. 2000, 3, 1301-1306. [CrossRef]

71. Wu, F.; Xu, H.D.; Guan, J.J.; Hou, Y.S.; Gu, J.H.; Zhen, X.C.; Qin, Z.H. Rotenone Impairs Autophagic Flux and Lysosomal Functions in Parkinson's Disease. Neuroscience 2015, 284, 900-911. [CrossRef] [PubMed]

72. Pan-Montojo, F.; Schwarz, M.; Winkler, C.; Arnhold, M.; O'Sullivan, G.A.; Pal, A.; Said, J.; Marsico, G.; Verbavatz, J.M.; RodrigoAngulo, M.; et al. Environmental Toxins Trigger PD-like Progression via Increased Alpha-Synuclein Release from Enteric Neurons in Mice. Sci. Rep. 2012, 2, 898. [CrossRef] [PubMed]

73. Vella, L.J.; Hill, A.F.; Cheng, L. Focus on Extracellular Vesicles: Exosomes and Their Role in Protein Trafficking and Biomarker Potential in Alzheimer's and Parkinson's Disease. Int. J. Mol. Sci. 2016, 17, 173. Available online: https://www.mdpi.com/1422 -0067/17/2/173/htm (accessed on 16 November 2021). [CrossRef] [PubMed]

74. Kim, J.; Inoue, K.; Ishii, J.; Vanti, W.B.; Voronov, S.V.; Murchison, E.; Hannon, G.; Abeliovich, A. A MicroRNA Feedback Circuit in Midbrain Dopamine Neurons. Science 2007, 317, 1220-1224. [CrossRef] [PubMed]

75. Lee, S.W.L.; Paoletti, C.; Campisi, M.; Osaki, T.; Adriani, G.; Kamm, R.D.; Mattu, C.; Chiono, V. MicroRNA Delivery through Nanoparticles. J. Control. Release 2019, 313, 80-95. [CrossRef] [PubMed]

76. Mukherjee, S.; Akbar, I.; Kumari, B.; Vrati, S.; Basu, A.; Banerjee, A. Japanese Encephalitis Virus Infected Microglial Cells Secrete Exosomes Containing Let-7a/b That Facilitate Neuronal Damage via Caspase Activation. J Neurochem. 2018, 149, 518-534. [CrossRef] [PubMed]

77. Huang, S.; Ge, X.; Yu, J.; Han, Z.; Yin, Z.; Li, Y.; Chen, F.; Wang, H.; Zhang, J.; Lei, P. Increased MiR-124-3p in Microglial Exosomes Following Traumatic Brain Injury Inhibits Neuronal Inflammation and Contributes to Neurite Outgrowth via Their Transfer into Neurons. FASEB J. 2018, 32, 512-528. [CrossRef] 
78. Jiang, R.; Rong, C.; Ke, R.; Meng, S.; Yan, X.; Ke, H.; Wu, S.; Azim, A. Differential Proteomic Analysis of Serum Exosomes Reveals Alterations in Progression of Parkinson Disease. Medicine 2019, 98, e17478. [CrossRef]

79. Raposo, G.; Stoorvogel, W. Extracellular Vesicles: Exosomes, Microvesicles, and Friends. J. Cell Biol. 2013, 200, 373-383. [CrossRef]

80. Vallelunga, A.; Ragusa, M.; Di Mauro, S.; Iannitti, T.; Pilleri, M.; Biundo, R.; Weis, L.; Di Pietro, C.; De Iuliis, A.; Nicoletti, A.; et al. Identification of Circulating MicroRNAs for the Differential Diagnosis of Parkinson's Disease and Multiple System Atrophy. Front. Cell. Neurosci. 2014, 8, 156. [CrossRef]

81. Botta-Orfila, T.; Morató, X.; Compta, Y.; Lozano, J.J.; Falgàs, N.; Valldeoriola, F.; Pont-Sunyer, C.; Vilas, D.; Mengual, L.; Fernández, M.; et al. Identification of Blood Serum Micro-RNAs Associated with Idiopathic and LRRK2 Parkinson's Disease. J. Neurosci. Res. 2014, 92, 1071-1077. [CrossRef] [PubMed]

82. Ding, H.; Huang, Z.; Chen, M.; Wang, C.; Chen, X.; Chen, J.; Zhang, J. Identification of a Panel of Five Serum MiRNAs as a Biomarker for Parkinson's Disease. Parkinsonism Relat. Disord. 2016, 22, 68-73. [CrossRef]

83. Khoo, S.K.; Petillo, D.; Kang, U.J.; Resau, J.H.; Berryhill, B.; Linder, J.; Forsgren, L.; Neuman, L.A.; Tan, A.C. Plasma-Based Circulating MicroRNA Biomarkers for Parkinson's Disease. J. Parkinson's Dis. 2012, 2, 321-331. [CrossRef] [PubMed]

84. Burgos, K.; Malenica, I.; Metpally, R.; Courtright, A.; Rakela, B.; Beach, T.; Shill, H.; Adler, C.; Sabbagh, M.; Villa, S.; et al. Profiles of Extracellular MiRNA in Cerebrospinal Fluid and Serum from Patients with Alzheimer's and Parkinson's Diseases Correlate with Disease Status and Features of Pathology. PLoS ONE 2014, 9, e94839. [CrossRef]

85. Cardo, L.F.; Coto, E.; de Mena, L.; Ribacoba, R.; Moris, G.; Menéndez, M.; Alvarez, V. Profile of MicroRNAs in the Plasma of Parkinson's Disease Patients and Healthy Controls. J. Neurol. 2013, 260, 1420-1422. [CrossRef]

86. Gui, Y.; Liu, H.; Zhang, L.; Lv, W.; Hu, X. Altered MicroRNA Profiles in Cerebrospinal Fluid Exosome in Parkinson Disease and Alzheimer Disease. Oncotarget 2015, 6, 37043-37053. [CrossRef]

87. Andersen, H.H.; Duroux, M.; Gazerani, P. MicroRNAs as Modulators and Biomarkers of Inflammatory and Neuropathic Pain Conditions. Neurobiol. Dis. 2014, 71, 159-168. [CrossRef]

88. Shi, M.; Liu, C.; Cook, T.J.; Bullock, K.M.; Zhao, Y.; Ginghina, C.; Li, Y.; Aro, P.; Dator, R.; He, C.; et al. Plasma Exosomal $\alpha$-Synuclein Is Likely CNS-Derived and Increased in Parkinson's Disease. Acta Neuropathol. 2014, 128, 639-650. [CrossRef]

89. Fraser, K.B.; Rawlins, A.B.; Clark, R.G.; Alcalay, R.N.; Standaert, D.G.; Liu, N.; West, A.B. Ser(P)-1292 LRRK2 in Urinary Exosomes Is Elevated in Idiopathic Parkinson's Disease. Mov. Disord. 2016, 31, 1543-1550. [CrossRef] [PubMed]

90. Figura, M.; Sitkiewicz, E.; Świderska, B.; Milanowski, Ł.; Szlufik, S.; Koziorowski, D.; Friedman, A. Proteomic Profile of Saliva in Parkinson's Disease Patients: A Proof of Concept Study. Brain Sci. 2021, 11, 661. [CrossRef]

91. Sturchler, E.; Cox, J.A.; Durussel, I.; Weibel, M.; Heizmann, C.W. S100A16, a Novel Calcium-Binding Protein of the EF-Hand Superfamily. J. Biol. Chem. 2006, 281, 38905-38917. [CrossRef] [PubMed]

92. A Comprehensive Characterisation of the Salivary Proteome of Patients with Parkinson's Disease-MDS Abstracts. Available online: https:/ / www.mdsabstracts.org/abstract/a-comprehensive-characterisation-of-the-salivary-proteome-of-patients-withparkinsons-disease/ (accessed on 25 November 2021).

93. Serrano, A.; Apolloni, S.; Rossi, S.; Lattante, S.; Sabatelli, M.; Peric, M.; Andjus, P.; Michetti, F.; Carrì, M.T.; Cozzolino, M.; et al. The S100A4 Transcriptional Inhibitor Niclosamide Reduces Pro-Inflammatory and Migratory Phenotypes of Microglia: Implications for Amyotrophic Lateral Sclerosis. Cells 2019, 8, 1261. [CrossRef] [PubMed]

94. Qiu, X.; Ping, S.; Kyle, M.; Longo, J.; Chin, L.; Zhao, L.-R. S100 Calcium-Binding Protein A9 Knockout Contributes to Neuroprotection and Functional Improvement after Traumatic Brain Injury. J. Neurotrauma 2020, 37, 950-965. [CrossRef]

95. Kaca-Oryńska, M.; Tomasiuk, R.; Friedman, A. Neuron-Specific Enolase and S 100B Protein as Predictors of Outcome in Ischaemic Stroke. Neurol. Neurochir. Pol. 2010, 44, 459-463. [CrossRef]

96. Schrank, B.R.; Aparicio, T.; Li, Y.; Chang, W.; Chait, B.T.; Gundersen, G.G.; Gottesman, M.E.; Gautier, J. Nuclear Arp2/3 Drives DNA Break Clustering for Homology-Directed Repair. Nature 2018, 559, 61-66. [CrossRef]

97. Baietti, M.F.; Zhang, Z.; Mortier, E.; Melchior, A.; Degeest, G.; Geeraerts, A.; Ivarsson, Y.; Depoortere, F.; Coomans, C.; Vermeiren, E.; et al. Syndecan-Syntenin-ALIX Regulates the Biogenesis of Exosomes. Nat. Cell Biol. 2012, 14, 677-685. [CrossRef]

98. Galindez, J.M.; Juwara, L.; Cressatti, M.; Gornitsky, M.; Velly, A.M.; Schipper, H.M. Salivary Heme Oxygenase-1: A Potential Biomarker for Central Neurodegeneration. J. Cent. Nerv. Syst. Dis. 2021, 13, 11795735211029114. [CrossRef] [PubMed]

99. Tenhunen, R.; Marver, H.S.; Schmid, R. The Enzymatic Conversion of Heme to Bilirubin by Microsomal Heme Oxygenase. Proc. Natl. Acad. Sci. USA 1968, 61, 748-755. [CrossRef]

100. Ayuso, P.; Martínez, C.; Pastor, P.; Lorenzo-Betancor, O.; Luengo, A.; Jiménez-Jiménez, F.J.; Alonso-Navarro, H.; Agúndez, J.A.G.; García-Martín, E. An Association Study between Heme Oxygenase-1 Genetic Variants and Parkinson's Disease. Front. Cell. Neurosci. 2014, 8, 298. [CrossRef]

101. Cressatti, M.; Galindez, J.M.; Juwara, L.; Orlovetskie, N.; Velly, A.M.; Eintracht, S.; Liberman, A.; Gornitsky, M.; Schipper, H.M. Characterization and Heme Oxygenase-1 Content of Extracellular Vesicles in Human Biofluids. J. Neurochem. 2021, 157, 2195-2209. [CrossRef] [PubMed]

102. Yao, Y.F.; Qu, M.W.; Li, G.C.; Zhang, F.B.; Rui, H.C. Circulating exosomal miRNAs as diagnostic biomarkers in Parkinson's disease. Eur. Rev. Med. Pharmacol. Sci. 2018, 22, 5278-5283.

103. Stuendl, A.; Kunadt, M.; Kruse, N.; Bartels, C.; Moebius, W.; Danzer, K.M.; Mollenhauer, B.; Schneide, A. Induction of $\alpha-$ Synuclein Aggregate Formation by CSF Exosomes from Patients with Parkinson's Disease and Dementia with Lewy Bodies. Brain 
2016, 139, 481-494. Available online: https:/ / academic.oup.com/brain/article/139/2/481/1753771?login=true (accessed on 10 October 2021). [CrossRef] [PubMed]

104. Olanow, C.W.; Agid, Y.; Mizuno, Y.; Albanese, A.; Bonuccelli, U.; Bonucelli, U.; Damier, P.; De Yebenes, J.; Gershanik, O.; Guttman, M.; et al. Levodopa in the Treatment of Parkinson's Disease: Current Controversies. Mov. Disord. 2004, 19, 997-1005. [CrossRef] [PubMed]

105. Holloway, R.G.; Shoulson, I.; Fahn, S.; Kieburtz, K.; Lang, A.; Marek, K.; McDermott, M.; Seibyl, J.; Weiner, W.; Musch, B.; et al. Pramipexole vs Levodopa as Initial Treatment for Parkinson Disease: A 4-Year Randomized Controlled Trial. Arch. Neurol. 2004, 61, 1044-1053. [CrossRef] [PubMed]

106. PubMed. A Five-Year Study of the Incidence of Dyskinesia in Patients with Early Parkinson's Disease Who Were Treated with Ropinirole or Levodopa. Available online: https://pubmed.ncbi.nlm.nih.gov/10816186/ (accessed on 25 November 2021).

107. Rinne, U.K.; Bracco, F.; Chouza, C.; Dupont, E.; Gershanik, O.; Marti Masso, J.F.; Montastruc, J.L.; Marsden, C.D. Early Treatment of Parkinson's Disease with Cabergoline Delays the Onset of Motor Complications. Results of a Double-Blind Levodopa Controlled Trial. The PKDS009 Study Group. Drugs 1998, 55 (Suppl. 1), 23-30. [CrossRef]

108. Oertel, W.H.; Wolters, E.; Sampaio, C.; Gimenez-Roldan, S.; Bergamasco, B.; Dujardin, M.; Grosset, D.G.; Arnold, G.; Leenders, K.L.; Hundemer, H.-P.; et al. Pergolide versus Levodopa Monotherapy in Early Parkinson's Disease Patients: The PELMOPET Study. Mov. Disord. 2006, 21, 343-353. [CrossRef] [PubMed]

109. Wajsbort, J. Post-Menopausal Bleeding after L-DOPA. N. Engl. J. Med. 1972, 286, 784. [PubMed]

110. Calm, D.; Reid, J. Antiparkinsonian Drugs: Pharmacological and Therapeutic Aspects. Drugs 1972, 4, $49-74$.

111. Calne, D.; Petrie, A.; Rao, S.; Reid, J.; Vakil, S. Action of L- $\alpha$-Methyldopa-Hydrazine on the Blood Pressure of Patients Receiving Levodopa. Br. J. Pharmacol. 1972, 44, 162. [CrossRef]

112. Riddoch, D. Gastritis and L-Dopa. Br. Med. J. 1972, 1, 53. [CrossRef]

113. Lieberman, A.; Goodgold, A.; Jonas, S.; Leibowitz, M. Comparison of Dopa Decarboxylase Inhibitor (Carbidopa) Combined with Levodopa and Levodopa Alone in Parkinson's Disease. Neurology 1975, 25, 911. [CrossRef]

114. Cedarbaum, J.M. Clinical Pharmacokinetics of Anti-Parkinsonian Drugs. Clin. Pharmacokinet. 1987, 13, 141-178. [CrossRef]

115. Sasahara, K.; Habara, T.; Morioka, T.; Nakajima, E. Bioavailability of Marketed Levodopa Preparation in Dogs and Parkinsonian Patients. J. Pharm. Sci. 1980, 69, 261-265. [CrossRef]

116. Yeh, K.; August, T.; Bush, D.; Lasseter, K.; Musson, D.; Schwartz, S.; Smith, M.; Titus, D. Pharmacokinetics and Bioavailability of Sinemet CR: A Summary of Human Studies. Neurology 1989, 39, 25-38. [PubMed]

117. Lieberman, A.; Estey, E.; Gopinathan, G.; Ohashi, T.; Sauter, A.; Goldstein, M. Comparative Effectiveness of Two Extracerebral DOPA Decarboxylase Inhibitors in Parkinson Disease. Neurology 1978, 28, 964. [CrossRef] [PubMed]

118. Wright, C.E.; Sisson, T.L.; Ichhpurani, A.K.; Peters, G.R. Steady-state Pharmacokinetic Properties of Pramipexole in Healthy Volunteers. J. Clin. Pharmacol. 1997, 37, 520-525. [CrossRef] [PubMed]

119. Etminan, M.; Gill, S.; Samii, A. Comparison of the Risk of Adverse Events with Pramipexole and Ropinirole in Patients with Parkinson's Disease. Drug Saf. 2003, 26, 439-444. [CrossRef] [PubMed]

120. Kaye, C.M.; Nicholls, B. Clinical Pharmacokinetics of Ropinirole. Clin. Pharmacokinet. 2000, 39, 243-254. [CrossRef]

121. Titlic, M.; Tonkic, A.; Jukic, I.; Lusic, I.; Dikanovic, M. Side Effects of Ropinirole in Patients with Idiopathic Parkinson's Disease. Bratisl. Lek. Listy 2008, 109, 273-275.

122. Batla, A.; Stamelou, M.; Mencacci, N.; Schapira, A.H.; Bhatia, K.P. Ropinirole Monotherapy Induced Severe Reversible Dyskinesias in Parkinson's Disease. Mov. Disord. 2013, 28, 1159. [CrossRef] [PubMed]

123. Sanford, M.; Scott, L.J. Rotigotine Transdermal Patch. CNS Drugs 2011, 25, 699-719. [CrossRef] [PubMed]

124. Chen, J.J.; Ly, A.-V. Rasagiline: A Second-Generation Monoamine Oxidase Type-B Inhibitor for the Treatment of Parkinson's Disease. Am. J. Health-Syst. Pharm. 2006, 63, 915-928. [CrossRef] [PubMed]

125. Chen, J.J.; Swope, D.M. Clinical Pharmacology of Rasagiline: A Novel, Second-generation Propargylamine for the Treatment of Parkinson Disease. J. Clin. Pharmacol. 2005, 45, 878-894. [CrossRef] [PubMed]

126. Azzaro, A.J.; Ziemniak, J.; Kemper, E.; Campbell, B.J.; VanDenBerg, C. Pharmacokinetics and Absolute Bioavailability of Selegiline Following Treatment of Healthy Subjects with the Selegiline Transdermal System $(6 \mathrm{Mg} / 24 \mathrm{~h})$ : A Comparison with Oral Selegiline Capsules. J. Clin. Pharmacol. 2007, 47, 1256-1267. [CrossRef]

127. Heinonen, E.; Myllylä, V. Safety of Selegiline (Deprenyl) in the Treatment of Parkinson's Disease. Drug Saf. 1998, 19, 11-22. [CrossRef]

128. Blair, H.A.; Dhillon, S. Safinamide: A Review in Parkinson's Disease. CNS Drugs 2017, 31, 169-176. [CrossRef]

129. Heikkinen, H.; Saraheimo, M.; Antila, S.; Ottoila, P.; Pentikäinen, P.J. Pharmacokinetics of Entacapone, a Peripherally Acting Catechol-O-Methyltransferase Inhibitor, in Man. Eur. J. Clin. Pharmacol. 2001, 56, 821-826. [CrossRef]

130. Brooks, D.J. Safety and Tolerability of COMT Inhibitors. Neurology 2004, 62, S39-S46. [CrossRef]

131. Assal, F.; Spahr, L.; Hadengue, A.; Rubbici-Brandt, L.; Burkhard, P.R. Tolcapone and Fulminant Hepatitis. Lancet 1998, $352,958$. [CrossRef]

132. Borges, N. Tolcapone-Related Liver Dysfunction. Drug Saf. 2003, 26, 743-747. [CrossRef]

133. Dingemanse, J.; Jorga, K.M.; Schmitt, M.; Gieschke, R.; Fotteler, B.; Zürcher, G.; Prada, M.; van Brummelen, P. Integrated Pharmacokinetics and Pharmacodynamics of the Novel Catechol-O-methyltransferase Inhibitor Tolcapone during First Administration to Humans. Clin. Pharmacol. Ther. 1995, 57, 508-517. [CrossRef] 
134. Scott, L.J. Opicapone: A Review in Parkinson's Disease. Drugs 2016, 76, 1293-1300. [CrossRef] [PubMed]

135. Almeida, L.; Rocha, J.F.; Falcão, A.; Palma, P.N.; Loureiro, A.I.; Pinto, R.; Bonifácio, M.J.; Wright, L.C.; Nunes, T.; Soares-da-Silva, P. Pharmacokinetics, Pharmacodynamics and Tolerability of Opicapone, a Novel Catechol-O-Methyltransferase Inhibitor, in Healthy Subjects. Clin. Pharmacokinet. 2013, 52, 139-151. [CrossRef]

136. Aoki, F.Y.; Sitar, D.S. Clinical Pharmacokinetics of Amantadine Hydrochloride. Clin. Pharmacokinet. 1988, 14, 35-51. [CrossRef]

137. Rees, W.; Harkins, J.; Woods, W.; Blown, R.; Lu, M.; Fenger, C.; Holland, R.; Chambers, T.; Tobin, T. Amantadine and Equine Influenza: Pharmacology, Pharmacokinetics and Neurological Effects in the Horse. Equine Vet. J. 1997, 29, 104-110. [CrossRef] [PubMed]

138. Aoki, F.Y.; Sitar, D.S.; Ogilvie, R.I. Amantadine Kinetics in Healthy Young Subjects after Long-term Dosing. Clin. Pharmacol. Ther. 1979, 26, 729-736. [CrossRef]

139. Dragašević-Mišković, N.; Petrović, I.; Stanković, I.; Kostić, V.S. Chemical Management of Levodopa-Induced Dyskinesia in Parkinson's Disease Patients. Expert Opin. Pharmacother. 2019, 20, 219-230. [CrossRef]

140. Pessoa, R.R.; Moro, A.; Munhoz, R.P.; Teive, H.A.; Lees, A.J. Apomorphine in the Treatment of Parkinson's Disease: A Review. Arq. Neuro-Psiquiatr. 2018, 76, 840-848. [CrossRef] [PubMed]

141. Whiteman, P.; Fowle, A.; Hamilton, M.; Peck, A.; Bye, A.; Dean, K.; Webster, A. Pharmacokinetics and Pharmacodynamics of Procyclidine in Man. Eur. J. Clin. Pharmacol. 1985, 28, 73-78. [CrossRef]

142. Wisher, D. Martindale: The Complete Drug Reference. J. Med. Libr. Assoc. 2012, 100, 815. [CrossRef]

143. Begbie, F.; Walker, G.; Kubba, H.; Sabharwal, A. Acute Colonic Pseudo-Obstruction in a Child Taking Trihexyphenidyl for Drooling: Prescribers Beware. Int. J. Pediatr. Otorhinolaryngol. 2015, 79, 932-934. [CrossRef] [PubMed]

144. Parkinson Study Group. Pramipexole vs Levodopa as Initial Treatment for Parkinson Disease: A Randomized Controlled Trial. Parkinson Study Group. JAMA 2000, 284, 1931-1938. [CrossRef]

145. PubMed. Toxicity of 6-Hydroxydopamine and Dopamine for Dopaminergic Neurons in Culture. Available online: https: / / pubmed.ncbi.nlm.nih.gov/1977925/ (accessed on 25 November 2021).

146. Spencer, J.P.; Jenner, A.; Aruoma, O.I.; Evans, P.J.; Kaur, H.; Dexter, D.T.; Jenner, P.; Lees, A.J.; Marsden, D.C.; Halliwell, B. Intense Oxidative DNA Damage Promoted by L-Dopa and Its Metabolites. Implications for Neurodegenerative Disease. FEBS Lett. 1994, 353, 246-250. [CrossRef]

147. Mena, M.A.; Pardo, B.; Casarejos, M.J.; Fahn, S.; García de Yébenes, J. Neurotoxicity of Levodopa on Catecholamine-Rich Neurons. Mov. Disord. 1992, 7, 23-31. [CrossRef] [PubMed]

148. Fahn, S. Is Levodopa Toxic? Neurology 1996, 47, S184-S195. [CrossRef] [PubMed]

149. Rajput, A.H. Levodopa Prolongs Life Expectancy and Is Non-Toxic to Substantia Nigra. Parkinsonism Relat. Disord. 2001, 8, 95-100. [CrossRef]

150. Hoehn, M.M. The Natural History of Parkinson's Disease in the Pre-Levodopa and Post-Levodopa Eras. Neurol. Clin. 1992, 10, 331-339. [CrossRef]

151. Hagenah, J.; Klein, C.; Sieberer, M.; Vieregge, P. Exogenous Levodopa Is Not Toxic to Elderly Subjects with Non-Parkinsonian Movement Disorders: Further Clinical Evidence. J. Neural Transm. 1999, 106, 301-307. [CrossRef] [PubMed]

152. Urso, D.; Chaudhuri, K.R.; Qamar, M.A.; Jenner, P. Improving the Delivery of Levodopa in Parkinson's Disease: A Review of Approved and Emerging Therapies. CNS Drugs 2020, 34, 1149-1163. [CrossRef]

153. Poewe, W.; Antonini, A.; Zijlmans, J.C.; Burkhard, P.R.; Vingerhoets, F. Levodopa in the Treatment of Parkinson's Disease: An Old Drug Still Going Strong. Clin. Interv. Aging 2010, 5, 229-238.

154. Titova, N.; Qamar, M.A.; Chaudhuri, K.R. The Nonmotor Features of Parkinson's Disease. Int. Rev. Neurobiol. 2017, 132, 33-54 [CrossRef]

155. Non-Oral Dopaminergic Therapies for Parkinson's Disease: Current Treatments and the Future. NPJ Parkinson's Dis. 2016, 2, 1-7. Available online: https:/ / www.nature.com/articles/npjparkd201623 (accessed on 25 November 2021).

156. Gut Dysfunction in Parkinson's Disease. Available online: https:/ /www.wjgnet.com/1007-9327/full/v22/i25/5742.htm (accessed on 25 November 2021).

157. Chaudhuri, K.R.; Qamar, M.A.; Rajah, T.; Loehrer, P.; Sauerbier, A.; Odin, P.; Jenner, P. Pharmacokinetics of Levodopa: Clinical Neuropharmacology. Available online: https://journals.lww.com/clinicalneuropharm/Citation/1984/03000/Pharmacokinetics_ of_Levodopa.2.aspx (accessed on 25 November 2021).

158. Eradication of Helicobacter pylori Infection Improves Levodopa Action, Clinical Symptoms and Quality of Life in Patients with Parkinson's Disease. Available online: https://journals.plos.org/plosone/article?id=10.1371/journal.pone.0112330 (accessed on 25 November 2021).

159. Dingemanse, J. Issues Important for Rational COMT Inhibition. Neurology 2000, 55, S24-S27.

160. Pardridge, W.M. Drug Transport across the Blood-Brain Barrier. J. Cereb. Blood Flow Metab. 2012, 32, 1959-1972. [CrossRef]

161. Abbott, N.J. Blood-Brain Barrier Structure and Function and the Challenges for CNS Drug Delivery. J. Inherit. Metab. Dis. 2013, 36, 437-449. [CrossRef]

162. Xia, X.; Wang, Y.; Huang, Y.; Zhang, H.; Lu, H.; Zheng, J.C. Exosomal MiRNAs in Central Nervous System Diseases: Biomarkers, Pathological Mediators, Protective Factors and Therapeutic Agents. Prog. Neurobiol. 2019, 183, 101694. [CrossRef]

163. Haney, M.J.; Klyachko, N.L.; Zhao, Y.; Gupta, R.; Plotnikova, E.G.; He, Z.; Patel, T.; Piroyan, A.; Sokolsky, M.; Kabanov, A.V.; et al. Exosomes as Drug Delivery Vehicles for Parkinson's Disease Therapy. J. Control. Release 2015, 207, 18-30. [CrossRef] 
164. Alvarez-Erviti, L.; Seow, Y.; Yin, H.; Betts, C.; Lakhal, S.; Wood, M.J.A. Delivery of SiRNA to the Mouse Brain by Systemic Injection of Targeted Exosomes. Nat. Biotechnol. 2011, 29, 341-345. [CrossRef]

165. Liu, L.; Li, Y.; Peng, H.; Liu, R.; Ji, W.; Shi, Z.; Shen, J.; Ma, G.; Zhang, X. Targeted Exosome Coating Gene-Chem Nanocomplex as "Nanoscavenger" for Clearing $\alpha$-Synuclein and Immune Activation of Parkinson's Disease. Sci. Adv. 2020, 6, eaba3967. [CrossRef]

166. Li, Q.; Wang, Z.; Xing, H.; Wang, Y.; Guo, Y. Exosomes Derived from MiR-188-3p-Modified Adipose-Derived Mesenchymal Stem Cells Protect Parkinson's Disease. Mol. Ther. Nucleic Acids 2021, 23, 1334-1344. [CrossRef] [PubMed]

167. Cooper, J.M.; Wiklander, P.B.O.; Nordin, J.Z.; Al-Shawi, R.; Wood, M.J.; Vithlani, M.; Schapira, A.H.V.; Simons, J.P.; El-Andaloussi, S.; Alvarez-Erviti, L. Systemic Exosomal SiRNA Delivery Reduced Alpha-Synuclein Aggregates in Brains of Transgenic Mice. Mov. Disord. 2014, 29, 1476-1485. [CrossRef] [PubMed]

168. Izco, M.; Blesa, J.; Schleef, M.; Schmeer, M.; Porcari, R.; Al-Shawi, R.; Ellmerich, S.; de Toro, M.; Gardiner, C.; Seow, Y.; et al. Systemic Exosomal Delivery of ShRNA Minicircles Prevents Parkinsonian Pathology. Mol. Ther. 2019, 27, 2111-2122. [CrossRef]

169. Qu, M.; Lin, Q.; Huang, L.; Fu, Y.; Wang, L.; He, S.; Fu, Y.; Yang, S.; Zhang, Z.; Zhang, L.; et al. Dopamine-Loaded Blood Exosomes Targeted to Brain for Better Treatment of Parkinson's Disease. J. Control. Release 2018, 287, 156-166. [CrossRef]

170. Ren, X.; Zhao, Y.; Xue, F.; Zheng, Y.; Huang, H.; Wang, W.; Chang, Y.; Yang, H.; Zhang, J. Exosomal DNA Aptamer Targeting $\alpha$-Synuclein Aggregates Reduced Neuropathological Deficits in a Mouse Parkinson's Disease Model. Mol. Ther. Nucleic Acids 2019, 17, 726-740. [CrossRef]

171. Zhao, Y.; Haney, M.J.; Gupta, R.; Bohnsack, J.P.; He, Z.; Kabanov, A.V.; Batrakova, E.V. GDNF-Transfected Macrophages Produce Potent Neuroprotective Effects in Parkinson's Disease Mouse Model. PLoS ONE 2014, 9, e106867. [CrossRef]

172. Lotvall, J.; Valadi, H. Cell to Cell Signalling via Exosomes Through EsRNA. Cell Adhes. Migr. 2007, 1, 156-158. [CrossRef]

173. Jarmalavičiūtè, A.; Pivoriūnas, A. Exosomes as a Potential Novel Therapeutic Tools against Neurodegenerative Diseases. Pharmacol. Res. 2016, 113, 816-822. [CrossRef]

174. Gangadaran, P.; Ahn, B.-C. Extracellular Vesicle- and Extracellular Vesicle Mimetics-Based Drug Delivery Systems: New Perspectives, Challenges, and Clinical Developments. Pharmaceutics 2020, 12, 442. [CrossRef]

175. Luo, S.; Du, L.; Cui, Y. Potential Therapeutic Applications and Developments of Exosomes in Parkinson's Disease. Mol. Pharm. 2020, 17, 1447-1457. [CrossRef] [PubMed]

176. DeMaagd, G.; Philip, A. Parkinson's Disease and Its Management: Part 1: Disease Entity, Risk Factors, Pathophysiology, Clinical Presentation, and Diagnosis. Pharm. Ther. 2015, 40, 504-532.

177. Haddad, F.; Sawalha, M.; Khawaja, Y.; Najjar, A.; Karaman, R. Dopamine and Levodopa Prodrugs for the Treatment of Parkinson's Disease. Molecules 2017, 23, 40. [CrossRef] [PubMed]

178. Colamartino, M.; Padua, L.; Meneghini, C.; Leone, S.; Cornetta, T.; Testa, A.; Cozzi, R. Protective Effects of L-Dopa and Carbidopa Combined Treatments on Human Catecholaminergic Cells. DNA Cell Biol. 2012, 31, 1572-1579. [CrossRef]

179. Gao, H.; Yang, Z.; Zhang, S.; Cao, S.; Shen, S.; Pang, Z.; Jiang, X. Ligand Modified Nanoparticles Increases Cell Uptake, Alters Endocytosis and Elevates Glioma Distribution and Internalization. Sci. Rep. 2013, 3, 2534. [CrossRef]

180. Kanazawa, T.; Taki, H.; Okada, H. Nose-to-Brain Drug Delivery System with Ligand/Cell-Penetrating Peptide-Modified Polymeric Nano-Micelles for Intracerebral Gliomas. Eur. J. Pharm. Biopharm. 2020, 152, 85-94. [CrossRef] [PubMed]

181. Attia, M.S.; Hassaballah, M.Y.; Abdelqawy, M.A.; Mohamed, M.E.; Farag, A.K.; Negida, A.; Ghaith, H.; Emam, S.E. An Updated Review of Mesoporous Carbon as Novel Drug Delivery System. Drug Dev. Ind. Pharm. 2021, 47, 1029-1037. [CrossRef] [PubMed]

182. Silindir Gunay, M.; Yekta Ozer, A.; Chalon, S. Drug Delivery Systems for Imaging and Therapy of Parkinson's Disease. Curr. Neuropharmacol. 2016, 14, 376-391. [CrossRef] [PubMed]

183. Record, M.; Subra, C.; Silvente-Poirot, S.; Poirot, M. Exosomes as Intercellular Signalosomes and Pharmacological Effectors. Biochem. Pharmacol. 2011, 81, 1171-1182. [CrossRef] [PubMed]

184. Zhou, W.; Fong, M.Y.; Min, Y.; Somlo, G.; Liu, L.; Palomares, M.R.; Yu, Y.; Chow, A.; O'Connor, S.T.F.; Chin, A.R.; et al. CancerSecreted MiR-105 Destroys Vascular Endothelial Barriers to Promote Metastasis. Cancer Cell 2014, 25, 501-515. [CrossRef] [PubMed]

185. Johnsen, K.B.; Burkhart, A.; Melander, F.; Kempen, P.J.; Vejlebo, J.B.; Siupka, P.; Nielsen, M.S.; Andresen, T.L.; Moos, T. Targeting Transferrin Receptors at the Blood-Brain Barrier Improves the Uptake of Immunoliposomes and Subsequent Cargo Transport into the Brain Parenchyma. Sci. Rep. 2017, 7, 10396. [CrossRef] [PubMed]

186. Björklund, A.; Dunnett, S.B. The Amphetamine Induced Rotation Test: A Re-Assessment of Its Use as a Tool to Monitor Motor Impairment and Functional Recovery in Rodent Models of Parkinson's Disease. J. Parkinson's Dis. 2019, 9, 17-29. [CrossRef]

187. Tamtaji, O.R.; Hadinezhad, T.; Fallah, M.; Shahmirzadi, A.R.; Taghizadeh, M.; Behnam, M.; Asemi, Z. The Therapeutic Potential of Quercetin in Parkinson's Disease: Insights into Its Molecular and Cellular Regulation. Curr. Drug Targets 2020, 21, 509-518. [CrossRef]

188. Qi, Y.; Guo, L.; Jiang, Y.; Shi, Y.; Sui, H.; Zhao, L. Brain Delivery of Quercetin-Loaded Exosomes Improved Cognitive Function in AD Mice by Inhibiting Phosphorylated Tau-Mediated Neurofibrillary Tangles. Drug Deliv. 2020, 27, 745-755. [CrossRef] [PubMed]

189. Halliwell, B.; Gutteridge, J.M.C. Role of Free Radicals and Catalytic Metal Ions in Human Disease: An Overview. Methods Enzymol. 1990, 186, 1-85. [PubMed]

190. Reich, S.G.; Savitt, J.M. Parkinson's Disease. Med. Clin. N. Am. 2019, 103, 337-350. [CrossRef] 
191. Dana, H.; Chalbatani, G.M.; Mahmoodzadeh, H.; Karimloo, R.; Rezaiean, O.; Moradzadeh, A.; Mehmandoost, N.; Moazzen, F.; Mazraeh, A.; Marmari, V.; et al. Molecular Mechanisms and Biological Functions of SiRNA. Int. J. Biomed. Sci. IJBS $2017,13,48-57$.

192. Lewis, J.; Melrose, H.; Bumcrot, D.; Hope, A.; Zehr, C.; Lincoln, S.; Braithwaite, A.; He, Z.; Ogholikhan, S.; Hinkle, K.; et al. In Vivo Silencing of Alpha-Synuclein Using Naked SiRNA. Mol. Neurodegener. 2008, 3, 19. [CrossRef]

193. Sharma, N.; Nehru, B. Curcumin Affords Neuroprotection and Inhibits $\alpha$-Synuclein Aggregation in Lipopolysaccharide-Induced Parkinson's Disease Model. Inflammopharmacology 2018, 26, 349-360. [CrossRef] [PubMed]

194. Zharikov, A.D.; Cannon, J.R.; Tapias, V.; Bai, Q.; Horowitz, M.P.; Shah, V.; El Ayadi, A.; Hastings, T.G.; Greenamyre, J.T.; Burton, E.A. ShRNA Targeting $\alpha$-Synuclein Prevents Neurodegeneration in a Parkinson's Disease Model. J. Clin. Investig. 2015, 125, $2721-2735$. [CrossRef] [PubMed]

195. Titze-de-Almeida, R.; Titze-de-Almeida, S.S. MiR-7 Replacement Therapy in Parkinson's Disease. Curr. Gene Ther. $2018,18,143-153$. [CrossRef]

196. Meng, X.; Zhong, J.; Zeng, C.; Yung, K.K.L.; Zhang, X.; Wu, X.; Qu, S. MiR-30a-5p Regulates GLT-1 Function via a PKC $\alpha$-Mediated Ubiquitin Degradation Pathway in a Mouse Model of Parkinson's Disease. ACS Chem. Neurosci. 2021, 12, 1578-1592. [CrossRef] [PubMed]

197. Mosquera-Heredia, M.I.; Morales, L.C.; Vidal, O.M.; Barceló, E.; Silvera-Redondo, C.; Vélez, J.I.; Garavito-Galofre, P. Exosomes: Potential Disease Biomarkers and New Therapeutic Targets. Biomedicines 2021, 9, 1061. [CrossRef]

198. Soliman, H.M.; Ghonaim, G.A.; Gharib, S.M.; Chopra, H.; Farag, A.K.; Hassanin, M.H.; Nagah, A.; Emad-Eldin, M.; Hashem, N.E.; Yahya, G.; et al. Exosomes in Alzheimer's Disease: From Being Pathological Players to Potential Diagnostics and Therapeutics. Int. J. Mol. Sci. 2021, 22, 10794. [CrossRef] [PubMed]

199. Nakano, M.; Fujimiya, M. Potential Effects of Mesenchymal Stem Cell Derived Extracellular Vesicles and Exosomal MiRNAs in Neurological Disorders. Neural Regen. Res. 2021, 16, 2359-2366. [CrossRef] [PubMed]

200. Benmelouka, A.Y.; Munir, M.; Sayed, A.; Attia, M.S.; Ali, M.M.; Negida, A.; Alghamdi, B.S.; Kamal, M.A.; Barreto, G.E.; Ashraf, G.M. Neural Stem Cell-Based Therapies and Glioblastoma Management: Current Evidence and Clinical Challenges. Int. J. Mol. Sci. 2021, 22, 2258. [CrossRef] [PubMed]

201. Yu, H.; Sun, T.; An, J.; Wen, L.; Liu, F.; Bu, Z.; Cui, Y.; Feng, J. Potential Roles of Exosomes in Parkinson's Disease: From Pathogenesis, Diagnosis, and Treatment to Prognosis. Front. Cell Dev. Biol. 2020, 8, 86. [CrossRef] [PubMed]

202. Tomlinson, P.R.; Zheng, Y.; Fischer, R.; Heidasch, R.; Gardiner, C.; Evetts, S.; Hu, M.; Wade-Martins, R.; Turner, M.R.; Morris, J.; et al. Identification of Distinct Circulating Exosomes in Parkinson's Disease. Ann. Clin. Transl. Neurol. 2015, 2, 353-361. [CrossRef]

203. Chen, S.-Y.; Lin, M.-C.; Tsai, J.-S.; He, P.-L.; Luo, W.-T.; Chiu, I.-M.; Herschman, H.R.; Li, H.-J. Exosomal 2' ,3'-CNP from Mesenchymal Stem Cells Promotes Hippocampus CA1 Neurogenesis/Neuritogenesis and Contributes to Rescue of Cognition/Learning Deficiencies of Damaged Brain. Stem Cells Transl. Med. 2020, 9, 499-517. [CrossRef] 